\title{
Chapter 5 \\ Valuing Waste - A Multi-method Analysis of the Use of Household Refuse from Cooking and Sanitation for Soil Fertility Management in Tanzanian Smallholdings
}

\author{
Ariane Krause
}

\begin{abstract}
The starting point of this work is the intention of two farmers' initiatives to disseminate locally developed and adapted cooking and sanitation technologies to smallholder households in Karagwe District, in northwest Tanzania. These technologies include improved cooking stoves (ICSs), such as microgasifiers, and a system combining biogas digesters and burners for cooking, as well as urine-diverting dry toilets, and thermal sterilisation/pasteurisation for ecological sanitation (EcoSan). Switching to the new alternatives could lead to a higher availability of domestic residues for soil fertility management. These residues include biogas slurry from anaerobic digestion, powdery biochar from microgasifiers and sanitised human excreta from EcoSan facilities. Such recycling-driven approaches address an existing problem for many smallholders in sub-Saharan Africa, namely, the lack of soil amenders to sufficiently replenish soil nutrients and soil organic matter (SOM) in soils used for agricultural activity. This example from Tanzania systematically examines the nexus of 'energy-sanitation-agriculture' in smallholder farming systems. The short-term experiments demonstrated that all soil amenders that were analysed could significantly enhance crop productivity. CaSa-compost - the product of co-composting biochar with sanitised human excreta - quadrupled grain yields. The observed stimulation of crop yield and also plant nutrition is attributed to improved nutrient availability caused by a direct increase of soil $\mathrm{pH}$ and of plantavailable phosphorus (P) in the soil. The assessment of the lasting soil implications revealed that $\mathrm{CaSa}$-compost and biogas slurry both show the long-term potential to roughly double yields of maize. Corresponding nutrient requirements can be adequately compensated through residue capturing and subsistence production of soil
\end{abstract}

This article is an excerpt from the author's doctoral thesis (Krause 2018). The text is, therefore, partly revised and partly reprinted.

\footnotetext{
A. Krause $(\bowtie)$

Leibniz Institute of Vegetable and Ornamental Crops (IGZ), Großbeeren, Germany

e-mail: Krause@igzev.de
} 
amenders. The potential of CaSa-compost for sustainable soil fertility management is superior to that of standard compost, especially with respect to liming, replenishing soil $\mathrm{P}$ and restoring SOM. Biogas slurry, however, yields inferior results in all aspects when compared to compost amendments.

Keywords Biochar · Bioenergy · Biogas slurry · Compost · Ecological sanitation · Soil amendments $\cdot$ Soil improvement $\cdot$ Terra preta practice $\cdot$ Waste as resource

\section{Introduction}

\subsection{Sustainable Food Production and the 'Energy-Sanitation-Agriculture' Nexus}

Providing a growing population with healthy food from sustainable production systems is one of the most urgent contemporary challenges for global societies and science. In this context, the EAT-Lancet Commission on Food, Planet, Health concludes that a 'great food transformation' is urgently needed and demands 'an agricultural revolution', with a focus on diets and food production practices that will help to achieve the UN Sustainable Development Goals, as well as the Paris Agreement on Climate Change (Willett et al. 2019). Regarding anthropogenic activities impacting the 'planetary boundaries' (which define a safe operating space for humanity on Earth), Springmann et al. (2018) showed that only the combination of (1) ambitious technological improvements, combined with (2) dietary changes towards more plant-based diets, and (3) the reduction in food loss and waste has the potential to keep the environmental impacts of the food system at bay. Technological changes are in this case particularly relevant for the environmental domains of global nitrogen (N) and phosphorus (P) application (ibid.). Furthermore, the International Assessment of Agricultural Knowledge, Science and Technology for Development (IAASTD), also known as the World Agriculture Report, sees 'agriculture at a crossroads' and calls for focusing on efficient, small-scale agroecosystems with nutrient cycles that are as closed as practicably possible (McIntyre et al. 2009). Circular economies (CE) and material cycling within the agroecosystem are, therefore, necessary to stay within a safe operating space for food systems and represent agreed prerequisites for long-term global food production, which has been promoted inter alia by Willett et al. (2019), Springmann et al. (2018), the UN Food and Agriculture Organization (FAO) (2014), Lal (2006, 2009), La Via Campesina (2015), McIntyre et al. (2009) and De Schutter (2011).

Whilst smallholder farmers cultivate at least half of the world's food crops (Graeub et al. 2016), many smallholders in sub-Saharan Africa nevertheless lack the resources to sufficiently replenish soil nutrients and soil organic matter (SOM) in 
soils depleted by agricultural activity (Buresh et al. 1997; Markwei et al. 2008). This is why smallholders are often trapped in a vicious circle: soil acidity and P scarcity lead to insufficient production of food crops, which in turn leads to insufficient availability of residual matter for soil fertility management. Here, (the CE) approach and considering waste as a resource can be essential for closing material loops. As an example, waste streams from cooking and from sanitation can be employed in recycling-driven soil fertility management. Residues from cooking that can be recovered as resources for agriculture include ashes from the most common three-stone fires, biochar (i.e. char particles) from a kind of improved cook stove called a 'microgasifier' and biogas slurry from biogas systems. Biochar in particular is rich in carbon (C), and its recovery can therefore contribute to restoring SOM, whilst biogas slurry is valued as nutrient-rich fertiliser. In addition, bioenergy can also be applied to sanitation processes in order to destroy or deactivate pathogens from human excreta. When managing human excreta, preventing the transmission of disease is an essential element of EcoSan. Sanitation, therefore, needs to take place at as early a stage as possible during the process (World Health Organization (WHO) 2006). Technological sanitation alternatives that make it possible to consider human excreta as a resource, rather than as waste, include the urine-diverting dry toilet (UDDT), which collects human excreta, as well as thermal sanitation via pasteurisation and composting to properly treat the collected matter. Once sanitation has been completed, urine and faeces constitute a valuable resource for recycling plant nutrients, including N, P, potassium (K) and micronutrients (Esrey et al. 2001). Such recycling practices around the 'energy-sanitation-agriculture nexus' thus create a link between the use of sustainable technologies for energy and sanitation services and the recovery of waste resources from cooking and EcoSan to produce recycling fertilisers for agriculture. However, within the broad field of recycling fertilisers, there is still a lack of knowledge on applicability and the agronomic and ecological potential in agricultural and horticultural practices, which is particularly required when promoting $\mathrm{CE}$ to vulnerable smallholder communities.

\subsection{Objectives and Outline}

Against this backdrop, it was the objective of the present study to investigate an applied example of integrated resource management around the energy-sanitationagriculture nexus, which is realised in Karagwe, Tanzania, and which combines the implementation of cooking and sanitation facilities and the recovery of residues. I was particularly interested to study the potential of recycling-driven soil fertility management to fill existing fertiliser gaps in smallholder farming.

In this article, I firstly describe the study area (Sect. 2) and thereafter introduce the local projects and their underlying technologies (Sect. 3). I then explain the methodologies I applied to analyse the agronomic potential of linking waste streams from cooking and sanitation with agriculture. In Sect.4, I summarise and discuss results from an exploratory study conducted on-site and from a model-based 
simulation of long-term effects. In Sect. 5, I present and discuss opportunities and challenges for the real-world application of the studied recycling practices, before I close with presenting the main conclusions of my work (Sect. 6).

\section{Description of the Study Area}

\subsection{Location and Climate}

Karagwe is one of eight districts in Kagera Region in northwest Tanzania ( $01^{\circ} 33^{\prime} \mathrm{S}$, $31^{\circ} 07^{\prime} \mathrm{E}$, alt. $1500-1600$ m.a.s.l.). Kagera is part of the Lake Victoria Basin and is located near to the volcanic areas of the East African Rift Zone. The typical terrain of Karagwe District consists of hills and valleys. Rainfall is bimodal (March-May and October-November) and varies between 500 and $2000 \mathrm{~mm} / \mathrm{year}$, whilst mean temperatures range from 20 to $28{ }^{\circ} \mathrm{C}$ during the day. This semi-arid and tropical savanna climate (according to the Köppen-Geiger climate classification in Peel et al. 2007) allows twice-yearly harvests for most annual crops. The regional economy is dominated by smallholder agriculture, with about $90 \%$ of households selling agricultural products grown on their farms (United Republic of Tanzania (URoT) 2012).

\subsection{Rural Livelihoods in Karagwe District}

On average, a Karagwe household comprises six individuals (URoT 2012). The main resource for cooking is biomass: $96 \%$ of households use firewood, whilst about 3\% use charcoal (ibid.). Sanitation facilities are mainly pit latrines: $88 \%$ of households use standard pit latrines, compared to just $4 \%$ of households using improved pit latrines; only $1 \%$ of households possess a system of flush or pour toilets in combination with septic tanks, and $6 \%$ do not have any toilet facilities at all (ibid.). These patterns, alongside population growth, have increased pressure on natural resources, including soil, open and running water, forests, etc., over the last three decades (Ogola 2013; Rugalema et al. 1994).

\subsection{The Agroecosystem in Karagwe}

Most farms in this region have less than one hectare of planted land and are fully or partly subsistent (URoT 2012). A farm usually comprises a large, permanently cultivated plot (a shamba, also known as a kibania) and small fields planted with annual crops (msiri, also known as omusiri or kikamba) (Baijukya and de Steenhuijsen 
Piters 1998; Rugalema et al. 1994). The shamba (meaning 'field' in Swahili; it is also translated as a 'banana-based home garden') typically features a multi-layer design with diverse crops: high-growing, shady perennial crops, such as banana plants or fruit and coffee trees, that are intercropped with low-growing, annual crops as cover crops, such as beans, cassava, wild varieties of African eggplant, etc. On msiri plots, annual crops such as maize, potatoes, cassava, vegetables, etc. are cultivated in proximity to each other ('intercropping') (ibid.). The shamba is the most important type of land use for agriculture in Kagera, accounting for $>40 \%$ of total agricultural land (URoT 2012). Msiri cultivation, meanwhile, is implemented on about one-fifth of the farmland (ibid.). Regarding soil fertility management, the shamba usually receives much more attention compared to the msiri fields (Rugalema et al. 1994).

\subsection{Soil Pre-conditions in Karagwe}

Soils in Karagwe and Kagera are commonly predominantly Ferralsols and Acrisols (Kenneth et al. 2003; DePauw 1984) but can also be classified as Andosols (Batjes 2011; Krause et al. 2016). Like many smallholders in sub-Saharan Africa, Karagwe farmers are challenged by soil constraints, including (1) soil erosion, (2) soil acidity and (3) nutrient deficiencies - in particular the scarcity of plant-available P. In the past, nutrient input and output flows were balanced by effective material cycling (Rugalema et al. 1994). However, the growing market economy over the last decades has increased the export of nutrients from the region, especially in cash crops, such as coffee and banana (ibid.). As a result, the current nutrient uptake by crops often exceeds the input from fertilisers (Baijukya et al. 2006; United Nations Environment Programme (UNEP) 2007). With regard to the regional economy, the local soil is amongst the most important production factors for local communities, who consequently assign significant importance to the conservation and amelioration of agricultural soils. In addition, increasing fragmentation of farmland due to population growth places ever higher demands on the land for sustaining food security and farm incomes (Rugalema et al. 1994). As a consequence, there is a strong demand for an increase in agricultural productivity.

\subsection{Soil Management Applied in Karagwe}

According to Tittonell (2016), farmers in East Africa often pay special attention to a certain portion of their land where specific, highly valued crops are cultivated. This may result in what Tittonell has described as 'islands of soil fertility'. Many farmers in Kagera are proud of their typically well-managed banana-based home gardens (Rugalema et al. 1994). The shamba commonly receives sufficient inputs of agricultural and domestic 'waste' as it directly surrounds the farm. The msiri, 
situated on close fields, often receives fewer inputs and is, therefore, typically more adversely affected by nutrient depletion. In regard to balancing inputs and outputs of soil nutrients for the shamba, Baijukya and de Steenhuijsen Piters (1998) showed that structurally poor households without cattle are most affected by declining soil fertility. As countermeasures, Baijukya and de Steenhuijsen Piters (1998) made recommendations including the increased use of compost and effective recycling of all household refuse, including human excreta. Standard compost in Karagwe contains a mixture of fresh and dried grasses, ash, kitchen waste and, depending on the availability, animal manure or leftovers from brewery processes (Krause et al. 2015). In addition, water is added (if available) to improve moisture content. Composting is carried out in batches and usually takes around 3-6 months. Compost heaps are often placed in shallow pits under the shade of trees and covered with soil and grasses to mitigate evaporation. In addition to compost, the most common soil fertility management measures are carpeting with grasses and mulching with harvest residues.

\section{Material and Methods}

As indicated in the previous sections, there is, for multiple reasons, a strong demand for soil fertility management and appropriate soil amenders in Karagwe. In particular, msiri cultivation has not yet been fully researched. For this reason, I focus on researching realistic options for managing the local Andosol through the use of locally available residues from cooking and sanitation technologies implemented in the case study projects (Fig. 5.1), which I introduce in the following section.

\subsection{Case Study Projects and Technologies}

Two farmers' initiatives in Karagwe and their German partners have recently developed a set of projects, which have two aims: (1) providing the local community with resource-efficient cooking and sanitation technologies, whilst (2) improving local crop production by rigorous on-farm recycling of residues from cooking and sanitation and recycling-oriented soil fertility management. The farmers' initiatives facilitate projects at a grass-roots level, namely, MAVUNO (Project for Improvement for Community Relief and Services) and CHEMA (Programme for Community Habitat Environmental Management). The three local projects are (1) Biogas Support for Tanzania (BiogaST), (2) Efficient Cooking in Tanzania (EfCoiTa) and (3) Carbonisation and Sanitation (CaSa). The perspective adopted in the implementation has mainly focused on the household level, but it also looked at the institutional level. The projects' technologies are explained schematically and implemented as illustrated in Figs. 5.2, 5.3, 5.4, 5.5, 5.6 and 5.7. 


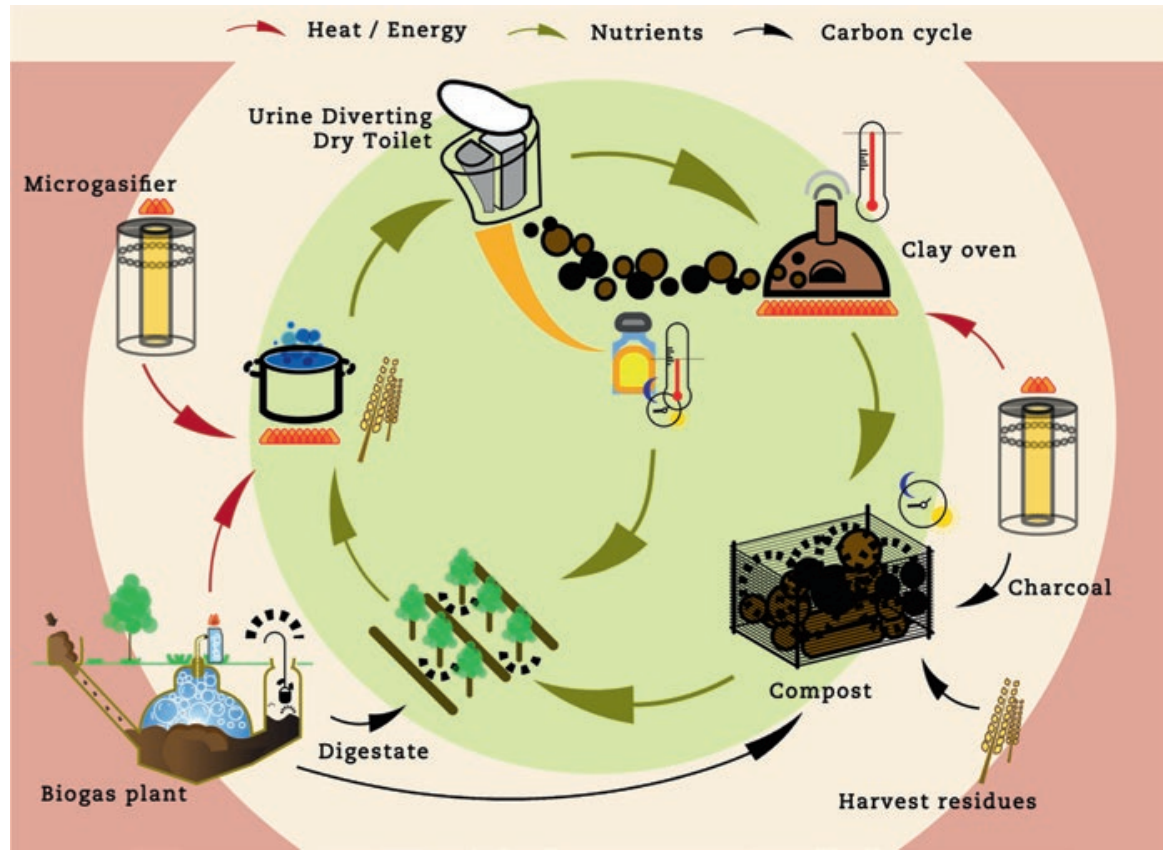

Fig. 5.1 Intersectional resource management using residues from cooking and EcoSan for soil improvement in the context of smallholder farming in Karagwe. (Infographic under creative commons licence (CC) by Ariane Krause and Lusi Ajonjoli)

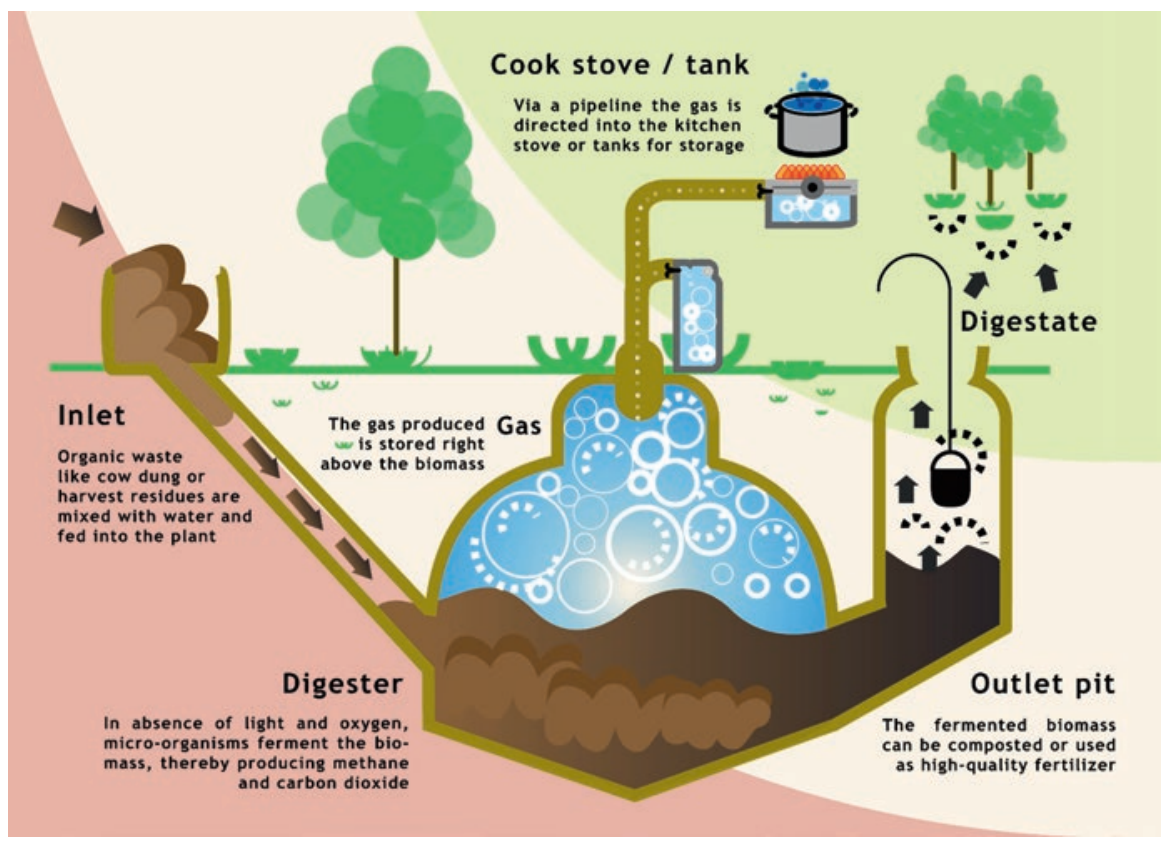

Fig. 5.2 Working principle of a small-scale biogas digester, including subsequent use of the biogas for cooking and of the biogas slurry/digestate for fertilisation. (Infographic (CC) by Lusi Ajonjoli) 

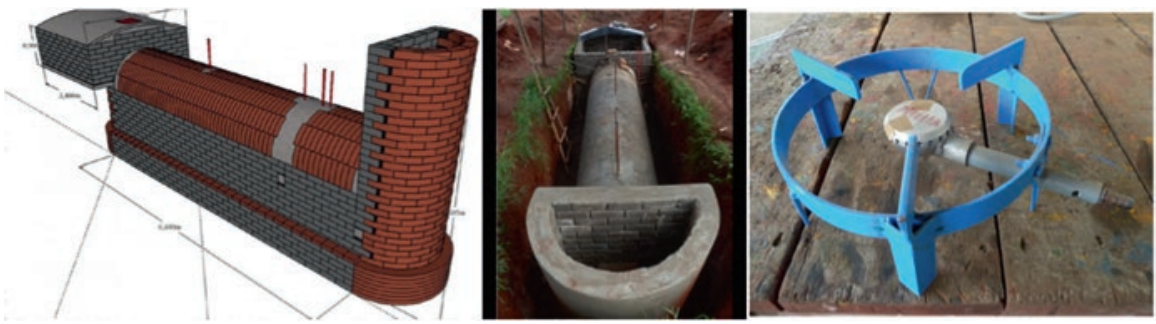

Fig. 5.3 The biogas system analysed in the present work comprises a small-scale biogas digester (left and centre) and a LOTUS biogas burner (right). (Source: Schrecker 2014)
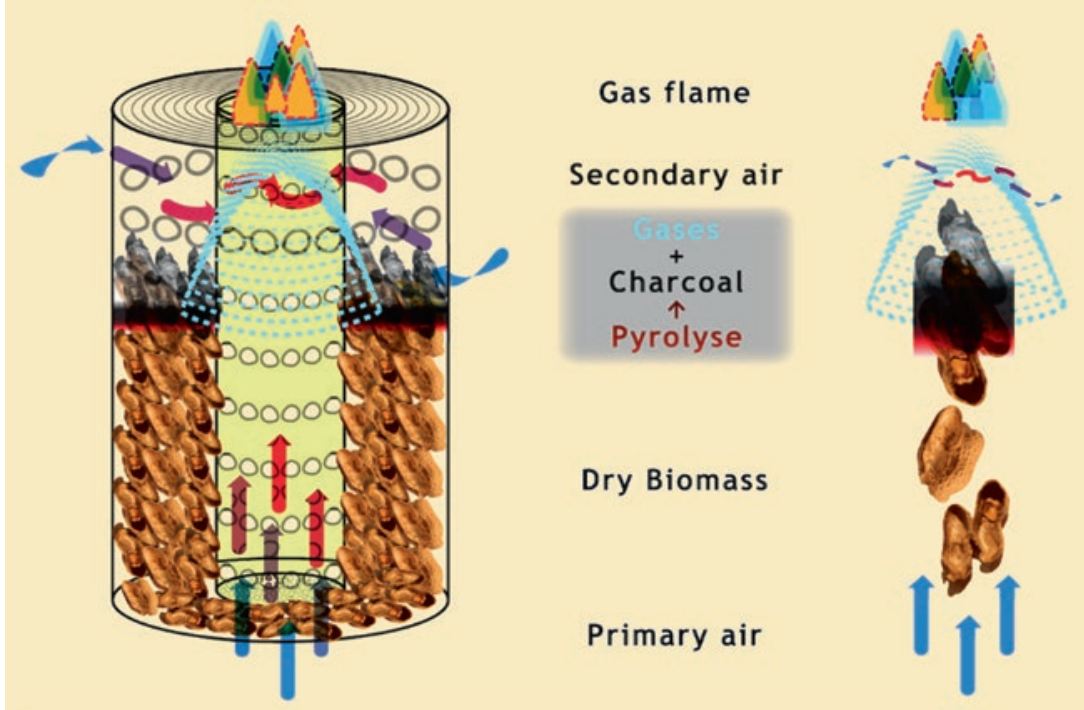

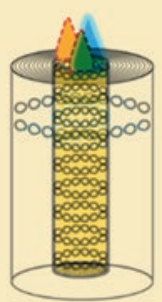

Side view

The gasisifer consists of two concentric cylinders. The perforation of the inner cylinder regulates the primary air flow, the holes in the outer cylinder control the secondary air flow.

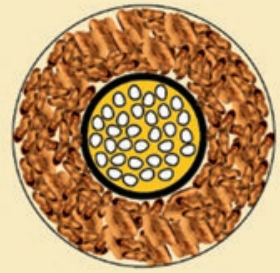

Top view

The biomass is put into the outer cylinder. The holes in the bottom of the inner cylinder allow primary air to stream in.

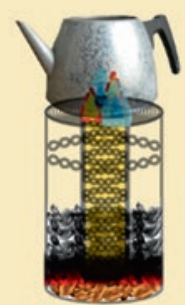

In operation

The biomass gasifies from top downwards, thereby producing flammable gases. They rise and fue the gas flame, when they mix with the secondary air. Biochar remains in the gasifier.

Fig. 5.4 Working principle of a microgasifier used for cooking, including co-production of biochar. The example given is of a stove operating with biomass in small pieces, such as groundnut shells. (Infographic (CC) by Lusi Ajonjoli) 

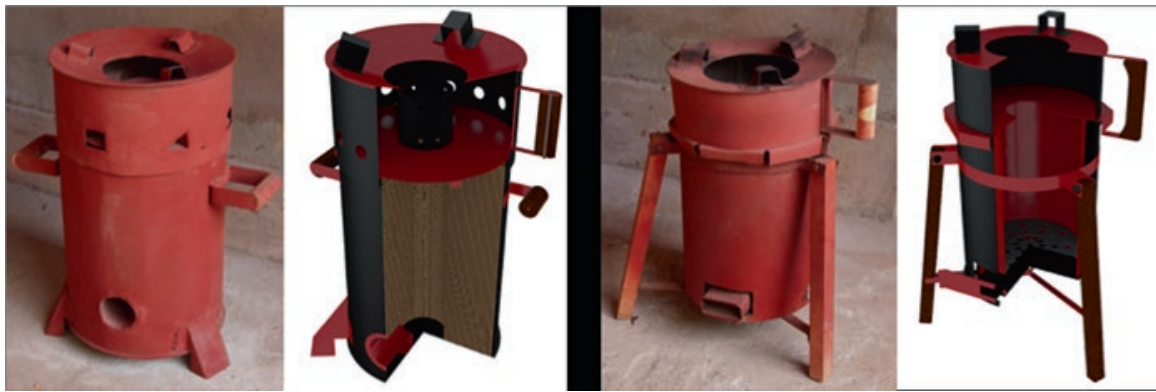

Fig. 5.5 The microgasifier stoves analysed in the present work comprise an improved sawdust stove (left) and a TLUD stove (right). (Sketches and photographs by D. Fröhlich)

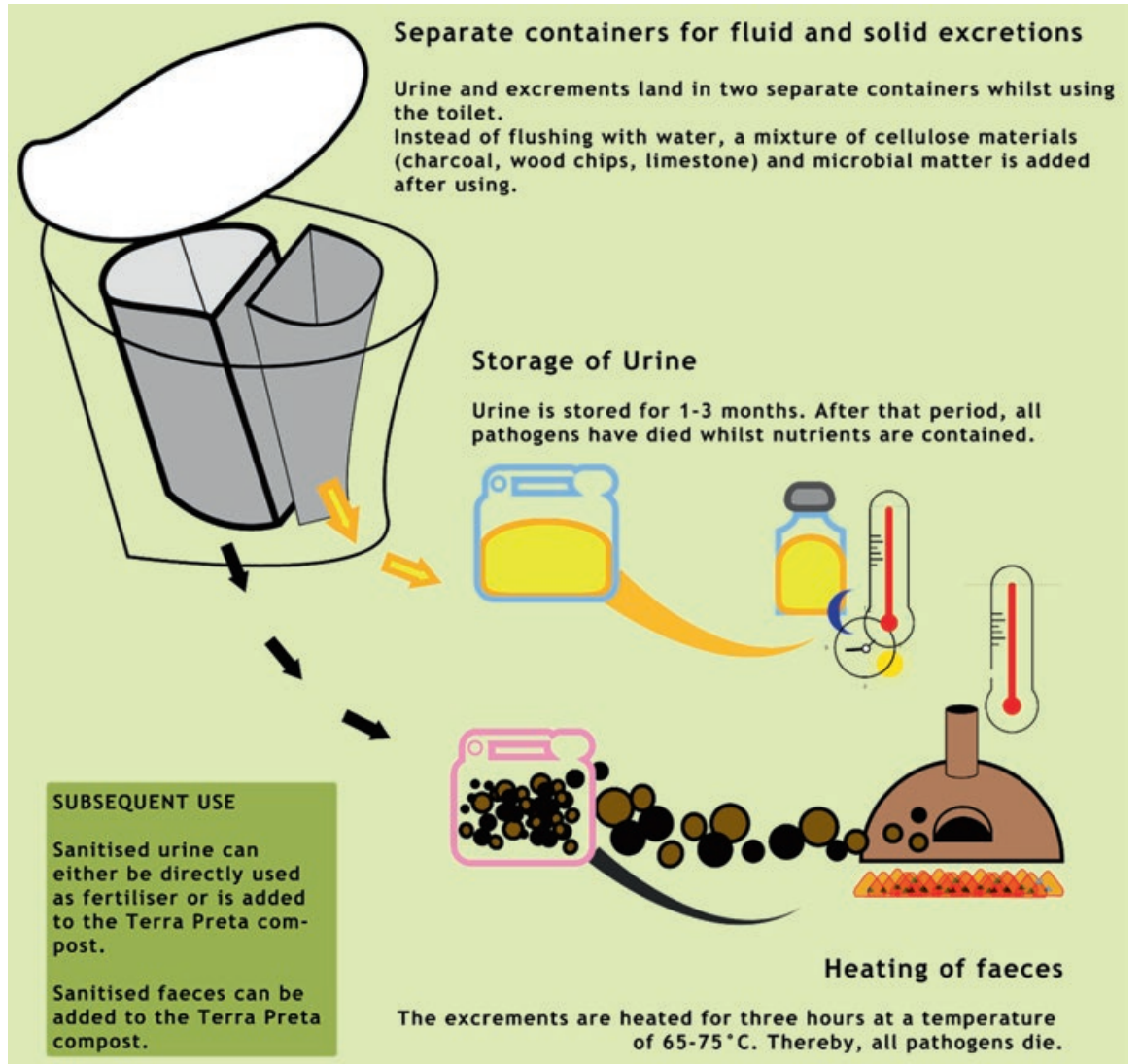

Fig. 5.6 Working principle of a UDDT, including possible paths for the subsequent treatment of urine and faeces, comparable to those analysed in the present study. (Infographic (CC) by Lusi Ajonjoli) 


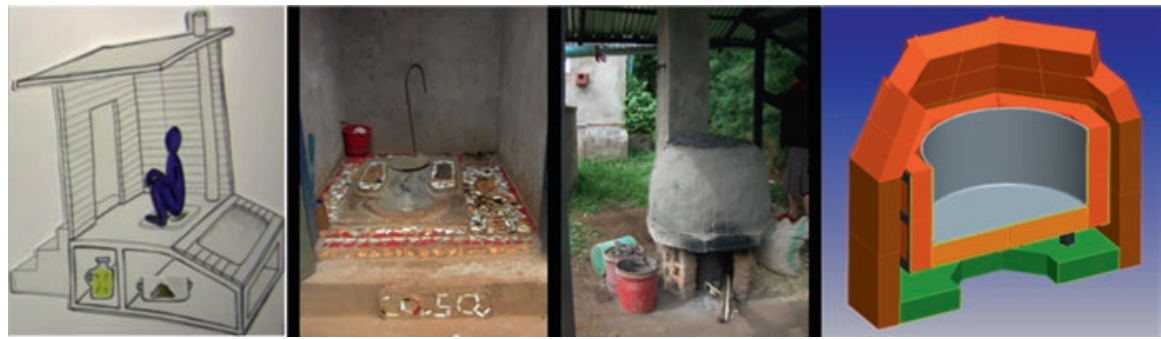

Fig. 5.7 The CaSa approach to EcoSan analysed in the present work comprises a UDDT (left) and sanitation oven (right). (Photographs by A. Krause, sketches from CaSa (2012))

The BiogaST project aims to provide cooking energy from a biogas system comprising a small-scale biogas digester with a plug-flow fermenter using harvest and kitchen residues and a 'LOTUS' biogas burner (Figs. 5.2 and 5.3).

The EfCoiTA project works with ICSs, such as top-lit updraft (TLUD) microgasifier stoves that operate with pieces of firewood or maize cobs and an improved sawdust microgasifier stove that utilises sawdust or coffee shells (Figs. 5.4 and 5.5). Both the biogas system and the ICSs have been designed with the aim of reducing, or even substituting for, the use of firewood.

The CaSa project deals with EcoSan, including a squat-type UDDT and a clay oven for thermal sanitation of excreta via pasteurisation, heated with a microgasifier (Figs. 5.6 and 5.7).

Overall, and if they are successfully implemented, it is expected that the introduced technologies will increase locally available soil amendments by applying (1) biogas slurry from anaerobic digestion, (2) powdery biochar from microgasifiers and (3) sanitised human excreta.

\subsection{Methods Applied to Study Recycling-Based Soil Management Strategies}

As part of my $\mathrm{PhD}$ research, I firstly characterised and assessed substrates derived from the case studies' pilot projects for agricultural use through laboratory analysis (Krause et al. 2015). These substrates included biogas slurry and CaSa-compost, the product of co-composting biochar with sanitised human excreta and other organic and mineral residues (e.g. harvest residues, grasses, brick particles, etc.; cf. Krause et al. 2015). Then I examined the short-term effects of the potential soil amenders on soil fertility and crop productivity in a practice-oriented field experiment carried out in Karagwe in 2014 (Krause et al. 2016). In this exploratory study, I used locally available substrates as soil amenders for the cultivation of locally grown and 
nutritionally desirable crop species, which I intercropped like common in msiri systems. I discussed differences observed in plant growth and crop nutrition, in relation to nutrient and water availability in the soil.

In addition, I also estimated and evaluated long-term effects of different fertilisation strategies on soil quality and the production of crops commonly cultivated in msiri systems. This assessment of lasting soil implications is based on using the 'Soil and Water Integrated Model' (SWIM) of the Potsdam Institute for Climate Impact Research (PIK - Potsdam-Institut für Klimafolgenforschung). The SWIM is a process-based, ecohydrological model, which integrates the impacts of climate and land management, or the 'way of farming', with hydrological processes, soil erosion, nutrient dynamics and vegetation (Krysanova et al. 2000). The model has already been calibrated for Tanzania, including the Kagera Region (Gornott et al. 2015,2016 ). The timeframe of the simulation is usually two decades (the period from 1993 to 2012). The SWIM evaluation considers several output parameters, including (1) annual crop yields of maize grains removed from the field during two seasons [t/ha], (2) soil $\mathrm{P}$ [kg/ha] comprising labile $\mathrm{P}\left(\mathrm{P}_{\mathrm{lab}}\right)$ as mineral $\mathrm{P}$ in the soil solution readily available for plant uptake and (3) soil $\mathrm{N}$ [kg/ha] comprising organic $\mathrm{N}\left(\mathrm{N}_{\text {org }}\right)$ that is readily mineralisable and $\mathrm{NO}_{3}{ }^{-}$as mineral $\mathrm{N}\left(\mathrm{N}_{\text {min }}\right)$ in the soil solution that is readily available for plant uptake. Input data to SWIM was based on two other studies that I conducted earlier by applying the material flow analysis method (cf. Krause and Rotter 2017) and material flow analysis in combination with the soil nutrient balances (cf. Krause and Rotter 2018). In total, the SWIM evaluation compared four scenarios (Table 5.1), reflecting (1) the 'current state' of soil fertility management with limited fertiliser application (AM1) and (2) 'improved' soil fertility management with fertiliser applications based on using residues from cooking and sanitation (AM2-AM4). In addition, and in accordance with local practices, carpeting with grasses and mulching with harvest residues was applied as a 'basic practice' in all scenarios.

Table 5.1. Scenarios analysed in the evaluation of long-term effects on soil fertility: scenarios AM1-AM4 reflect differences in soil management practices through the use of the analysed substrates as fertilisers in the msiri

\begin{tabular}{|c|c|c|}
\hline Abbr. & Name & Fertiliser application for maize \\
\hline AM1 & 'Current state' & None \\
\hline AM2 & BiogaST scenario & Biogas slurry and urine \\
\hline AM3 & 'Optimistic' CaSa scenario ${ }^{a}$ & CaSa-compost and urine \\
\hline AM4 & 'Pessimistic' CaSa scenario ${ }^{\mathrm{b}}$ & CaSa-compost and urine \\
\hline
\end{tabular}

The abbreviation 'AM' reflects the 'agroecosystem' of a msiri

${ }^{a}$ With comparatively higher yield assumptions based on empirical results gained with CaSacompost in Krause et al. (2015)

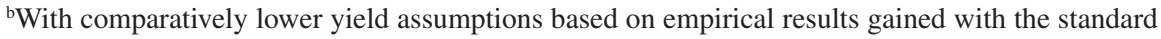
compost in Krause et al. (2015) 


\section{Discussion of Results}

This chapter summarises and discusses the results of the three evaluation methods applied. Key findings focusing on the potential for soil fertility management in Karagwe are summed up in 4.4 .

\subsection{Laboratory-Based Characterisation of Locally Available Substrates}

With respect to the assessment of locally available biogas slurry, standard compost and CaSa-compost for their fertilisation potential, the analysis of nutrient concentrations and nutrient availability revealed the following initial findings (cf. Krause et al. 2015): all treatments tested are characterised by sufficient nutrient concentrations for appropriate plant fertilisation and adequate nutrient ratios to avoid immobilisation of nutrients in the soil. They show good liming potential compared to other soil amendments, such as poultry or cattle manure, ammonium sulphate, urea, etc. The CaSa-compost shows an outstanding fertilisation potential, with the highest concentration of all analysed nutrients: for example, $\mathrm{P}$ concentration in CaSacompost is $1.7 \mathrm{~g} / \mathrm{dm}^{3}$ compared to 0.5 and $0.3 \mathrm{~g} / \mathrm{dm}^{3}$ in standard compost and biogas slurry, respectively. Also, regarding its liming effect, CaSa-compost is outstanding, with $7.8 \mathrm{~kg} \mathrm{CaO} / \mathrm{kg} \mathrm{N}$, compared to 2.6 and $3.4 \mathrm{~kg} \mathrm{CaO} / \mathrm{kg} \mathrm{N}$ of the standard compost and biogas slurry, respectively.

\subsection{Empirical Study of the Use of Locally Available Substrates as Soil Fertility Improvers}

After the initial characterisation of substrates, a subsequent one-season experiment provided empiric evidence of the immediate effects on soil fertility and biomass growth (Krause et al. 2016). With respect to soil physicochemical properties, I found that the availability of nutrients in the soil improved, in particular, after amending the Andosol with CaSa-compost, due to (1) significantly higher addition of total $\mathrm{P}\left(\mathrm{P}_{\text {tot }}\right)$ with comparable doses of $\mathrm{N}_{\min }$ and (2) a significant effect on soil $\mathrm{pH}$, which is attributed to biochar contained in CaSa-compost. Levels of soil $\mathrm{P}$ rose significantly after the experiment. In soil amended with CaSa-compost, soil $\mathrm{P}$ reached a concentration of calcium acetate lactate soluble $\mathrm{P}\left(\mathrm{P}_{\mathrm{CAL}}\right)$ of $4.4 \mathrm{mg} / \mathrm{kg}$, compared to $0.5 \mathrm{mg} / \mathrm{kg}$ in unamended control plots. No significant effect was observed on the availability of soil water, on concentrations of total organic carbon or on effective cation exchange capacity for any of the amendments tested. With respect to biomass growth and crop productivity, I found that biomass of maize increased in particular, when using CaSa-compost. Grain yields of maize in soil 


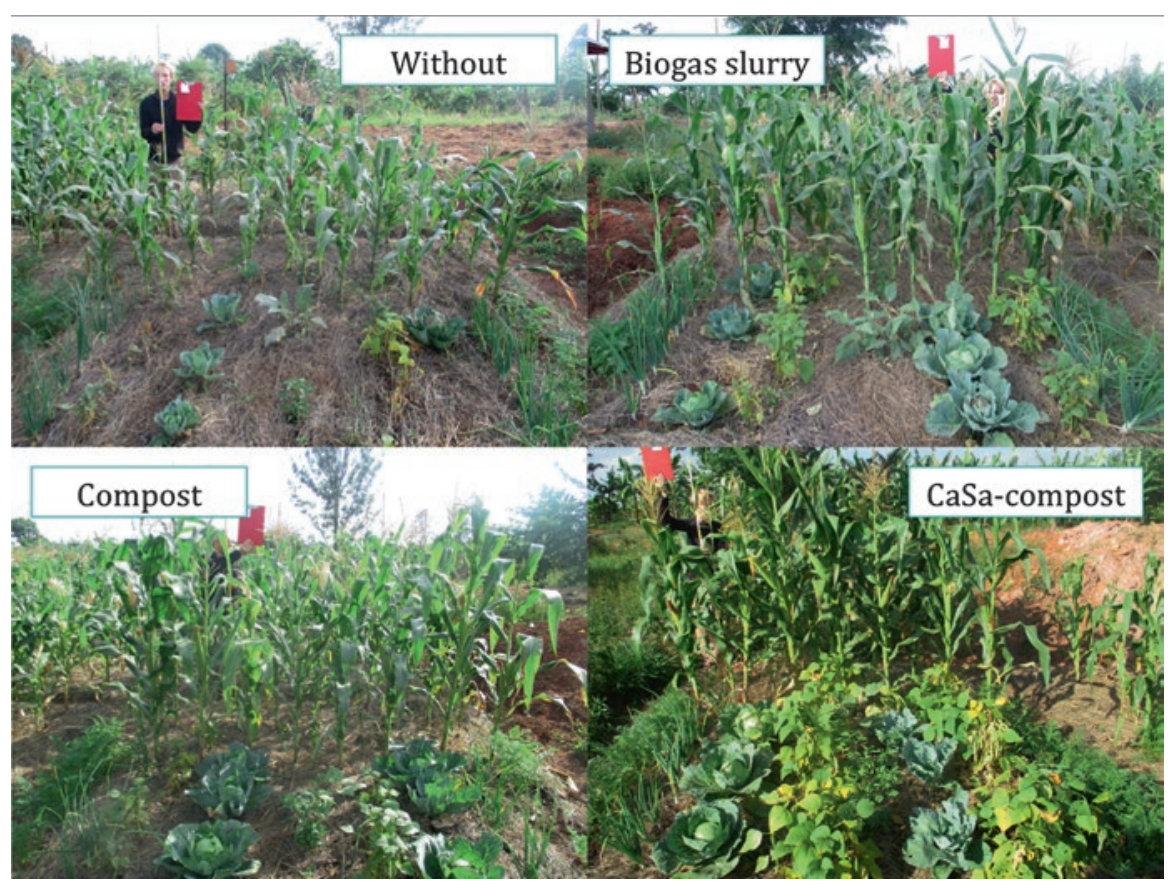

Fig. 5.8 Progress of the field experiment - 60 days after initiating the experiment with sowing of maize: an untreated plot ('without'), compared to plots amended with biogas slurry, standard compost and CaSa-compost. (Source: photographs taken by A. Krause on 2 June 2014)

treated with CaSa-compost, standard compost or biogas slurry increased to about $400 \%, 290 \%$ and $240 \%$, respectively, when compared to yields in unamended soil (Fig. 5.8). Biomass and yields of beans and onions significantly increased in the case of soil amended with CaSa-compost and standard compost only, whilst plant growth of cabbage clearly increased for all three amendments tested. Finally, and with respect to plants' nutrient status, I found that the total uptake of nutrients $(\mathrm{N}$, $\mathrm{P}, \mathrm{K}$, calcium $(\mathrm{Ca})$, magnesium $(\mathrm{Mg})$ and zinc $(\mathrm{Zn}))$ into maize grains increased significantly for all treatments in particular, for plants grown in plots amended with CaSa-compost. Primary response of maize plants is related to mitigated deficiency of soil P.

\subsection{SWIM}

The SWIM-based evaluation of the long-term effects of the recycling practices on crop yields and soil nutrients revealed the following findings. With respect to crop growth, SWIM predicts that annual maize yields would slightly, but continuously, decrease over a period of two decades under current soil management, as the linear 


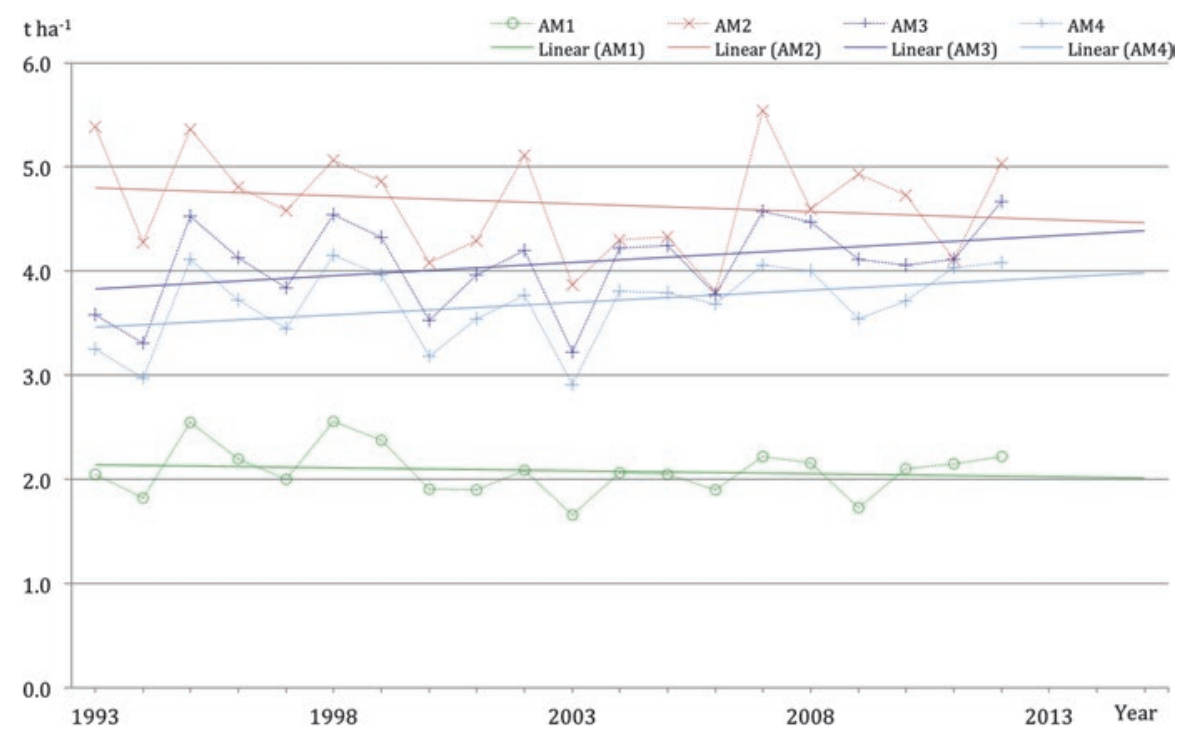

Fig. 5.9 Temporal shifting of annual crop yields from the SWIM analysis: calculated annual crop yields from the SWIM for the period 1993 until 2012

trend line in Fig. 5.9 indicates for AM1. Likewise, yields calculated for the BiogaST scenario decrease over the timeframe simulated, whilst grain yields estimated for the case of CaSa scenarios clearly increase over two decades. Furthermore, according to SWIM, yields of maize grains more or less double in scenarios AM2-AM4, compared with the baseline scenario AM1. However, (long-term) yields estimated with SWIM for BiogaST and CaSa scenarios increase to a lesser extent when compared with (short-term) empirical findings. Mean values of scenarios AM2, AM3 and AM4 are about $85 \%, 45 \%$ and $60 \%$ of annual yields projected from empirical data, respectively. Yields simulated for AM1 are, meanwhile, comparable to those realised in unamended soil during the field experiment (Krause et al. 2016) and fit with average grain yields reported for the region (Statistical Database of the FAO (FAOSTAT) 2012; Kimaro et al. 2009; Mourice et al. 2014). Yields simulated for scenarios AM2-AM4 are comparable to approximate yields required to reach world food security by 2025-2050 (Lal 2009).

Overall, according to SWIM, yields are higher for the case of using biogas slurry compared to using CaSa-compost, which is inconsistent with my empirical findings. I assume that SWIM overestimates higher inputs of Nmin with biogas slurry compared to CaSa-compost. By contrast, the residual effects of Norg applied and higher inputs of Ptot with CaSa-compost compared to biogas slurry are probably underestimated. Nonetheless, I observed empirically that maize plants directly react, in particular, to improved $\mathrm{P}$ fertilisation (Krause et al. 2016).

With respect to soil nutrient statuses, time series for Plab in the soil (Fig. 5.10) show a slight decrease of contents in AM1, which means that P is continuously depleted under current state conditions. However, in the BiogaST scenario, the 


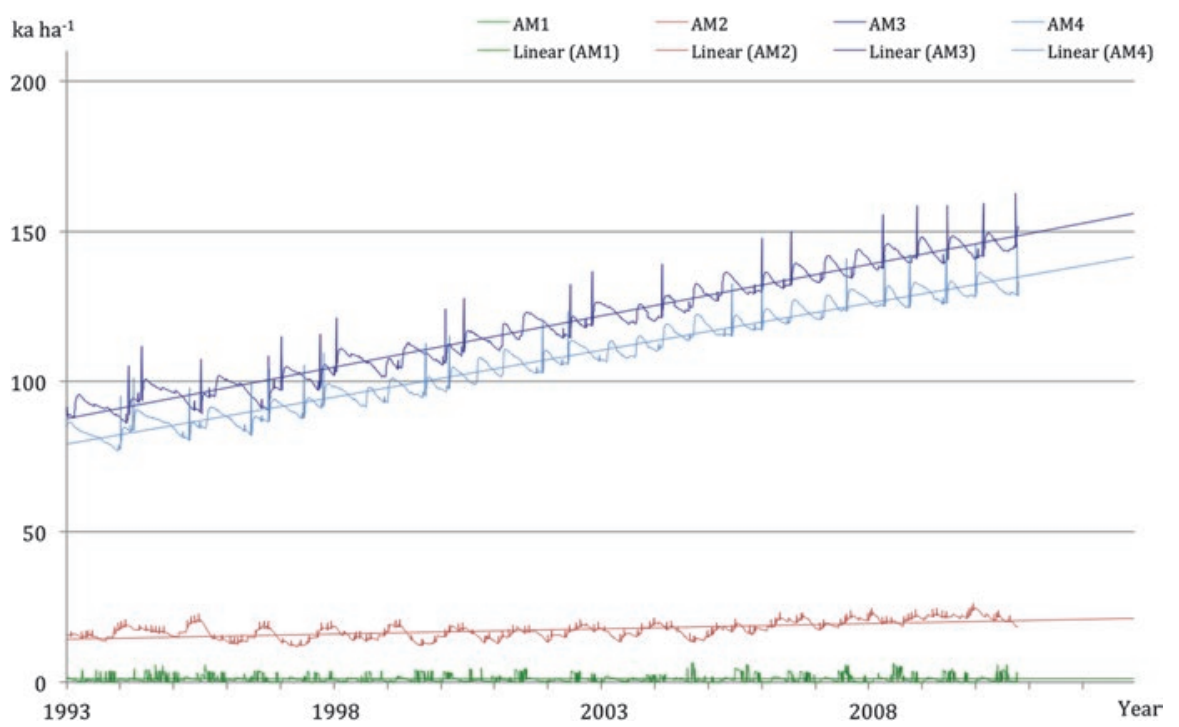

Fig. 5.10 Temporal shifting of content of $\mathrm{P}_{\mathrm{lab}}$ in the soil from the SWIM analysis: calculated content of $\mathrm{P}_{\text {lab }}$ in the soil from the SWIM analysis for the period 1993 until 2012

content of Plab in the soil slightly increases, whilst the increase is clearly superior in both CaSa scenarios.

SWIM further projects a clear increase of $\mathrm{N}_{\text {org }}$ in the soil for CaSa scenarios, whilst in the BiogaST scenario, $\mathrm{N}_{\text {org }}$ only slightly increases over two decades (Fig. 5.11). Under current soil management practices, however, the level of Norg in the soil remains constant over time. Simulated concentrations of $\mathrm{NO}_{3}{ }^{-}$in the soil fluctuate widely over the two decades, as was to be expected, pursuant to Finck (2007). The mean over two decades, simulating BiogaST and CaSa scenarios, is nearly seven and four times higher compared to the current state, respectively. Hence, according to SWIM, amending the soil with CaSa-compost offers outstanding potential in regard to continuously replenishing the soil nutrient statuses of $\mathrm{N}_{\text {org }}$ and $\mathrm{P}_{\text {lab. }}$.

With annual depletion or replenishment rates, on the one hand, and certain target values of soil $\mathrm{P}$, on the other, it is possible to estimate potential timeframes for $\mathrm{P}$ replenishment. I found that a period of 30-300 years of continuously amending the local soil with $\mathrm{CaSa}$-compost is required to reach ordinary benchmarks of extractable soil P ranging from 100 to 800 kg/ha (Finck 2007; Landon 1991). Meanwhile, more than 700 years of constant $\mathrm{CaSa}$ practice are required to reach an extremely high, Terra Preta-like concentration of about $2500 \mathrm{~kg} / \mathrm{ha}$ (Falcão et al. 2009). However, when using biogas slurry, the timeframe expands from several centuries to several millennia, depending on the target value. (Contents refer to a $1 \mathrm{~m}$ layer of topsoil.) 


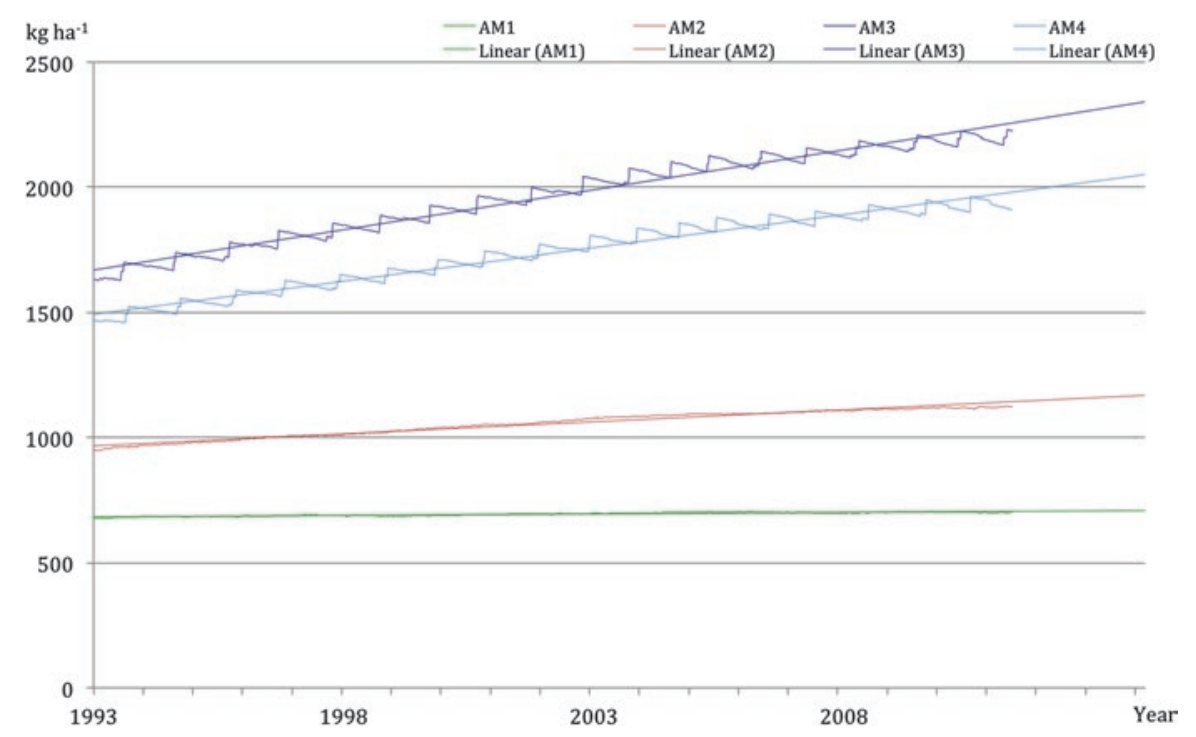

Fig. 5.11 Temporal shifting of the content of $\mathrm{N}_{\text {org }}$ in the soil from the SWIM analysis: calculated content of $\mathrm{N}_{\text {org }}$ in the soil from the SWIM analysis for the period 1993 until 2012

\subsection{Soil Fertility Management Around the Energy-Sanitation-Agriculture Nexus}

The evaluation of opportunities and challenges when using substrates analysed for 'sustainable' soil fertility management in Karagwe focuses on the potential for (A) replenishing soil $\mathrm{P}$, (B) mitigating soil acidity, (C) restoring SOM, (D) sequestering $\mathrm{C}$ and (E) increasing crop yields. In the following paragraphs, I briefly summarise the most relevant findings of my research with regard to this potential.

(A). A direct increase of soil $\mathrm{P}$ is practically possible with the addition of CaSacompost at a rate of about $140 \mathrm{~kg} \mathrm{P}_{\text {tot }}$ /ha (Krause et al. 2016). Adding biogas slurry or Karagwe standard compost at lower supply rates of 40 or $70 \mathrm{~kg} \mathrm{P}$ tot ha, respectively, is insufficient to increase concentrations of soil $\mathrm{P}$ over the course of one season (ibid.). Nevertheless, on a farm level, the theoretic potential for annual $\mathrm{P}$ replenishment rates ranges between 20 and $60 \mathrm{~kg} \mathrm{P}_{\text {tot }} / \mathrm{ha}$ (Krause and Rotter 2018). The $\mathrm{P}$ application rates estimated for CaSa-compost and standard compost are similar and are in the upper half of the range presented. The potential of regular annual $\mathrm{P}$ applications is, therefore, sufficient for $\mathrm{P}$ fertilisation and $\mathrm{P}$ replenishment, pursuant to the recommendations of Buresh et al. (1997) and Nziguheba (2001). Potential P applications with biogas slurry, however, barely meet the minimum demand for $\mathrm{P}$ fertilisation on degraded soils with strong $\mathrm{P}$ fixation characteristics (ibid.). According to SWIM (Sect. 4.3), long-term amendments of CaSa-compost demonstrate the clear potential to steadily increase soil $\mathrm{P}$ and therefore remedy $\mathrm{P}$ scarcity. This 
is not, however, the case when using biogas slurry. In practice, adequate levels of soil P support adaptation to, and mitigation of, the effects of climate change as a sufficient supply of soil $\mathrm{P}$ helps plants to root more deeply. This, in turn, makes crops less vulnerable to drought (Batjes and Sombroek 1997).

(B). A direct increase of soil $\mathrm{pH}$, i.e. after a one-off soil amendment, is only possible with CaSa-compost with a liming potential corresponding to about $2000 \mathrm{~kg} \mathrm{CaO} / \mathrm{ha}$ (Krause et al. 2016). Amending the soil with biogas slurry or Karagwe standard compost, in application rates equivalent to liming with 300 or $700 \mathrm{~kg} \mathrm{CaO} / \mathrm{ha}$, respectively, is not sufficient to increase soil $\mathrm{pH}$ over the course of a single season (ibid). The theoretical annual liming potential estimated in Krause and Rotter (2018) indicates that both CaSa-compost and Karagwe standard compost are feasible for maintaining soil pH (Finck 2007), whilst biogas slurry only fulfils the minimum requirements for liming, pursuant to Horn et al. (2010). Overall, acidity management through liming is an important soil management practice in order to strengthen nutrient-cycling processes (Batjes and Sombroek 1997). This means that an increase in soil $\mathrm{pH}$ through liming, as demonstrated especially for CaSa-compost, promotes nutrient availability in the soil and, thus, plant uptake of $\mathrm{P}$ and $\mathrm{N}$. As a consequence, on-farm nutrient recycling becomes more efficient and agricultural activity more productive.

(C). In my experiment, none of the tested soil amendments practically altered total C content of soil over the course of a single cropping season after the application of 150 or $500 \mathrm{~g} \mathrm{C} / \mathrm{m}^{2}$ with either biogas slurry or composts (Krause et al. 2016). The theoretical annual potential $\mathrm{C}$ contents in CaSa-compost and biogas slurry, meanwhile, are sufficient for restoring SOM consumed during the cultivation of maize in a field with areas of about 0.2 and 0.1 ha, respectively (Krause and Rotter 2017). Using potentially available CaSa-compost or standard compost for soil fertility management demonstrates that it is theoretically possible to restore sufficient $\mathrm{C}$ to the soil to surpass the humus consumption of C of those crops grown in msiri fields (Krause and Rotter 2018). In contrast, the $\mathrm{C}$ contained in biogas slurry barely balances SOM consumed during crop cultivation. To sum up, these findings indicate that only compost amendments demonstrate the theoretical potential to replenish SOM and also to sequester C in the long term; biogas slurry does not.

(D). Amongst the substrates analysed, CaSa-compost is particularly promising for sequestering $\mathrm{C}$, due to the content of biochar recovered from household cooking and sanitation. Biochar has the potential for $\mathrm{C}$ sequestration due to the following factors: (1) it originates in renewable biomasses (Christensen et al. 2009); and (2) it is characterised by relatively recalcitrant organic compounds, which promise the long-term stability of biochar in the soil (Lehmann and Joseph 2009). The context of the present analysis further promotes $C$ sequestration, as the local soil is known for its outstanding capacity to accumulate organic C. Andosols tend to protect organic matter from degradation by forming either metal-humus (i.e. often $\mathrm{Al}-\mathrm{Fe}$ ) or allophane-organo complexes (Zakharova et al. 2015). Therefore, and according to Chesworth (2008), 
Andosols have the potential to act as $\mathrm{CO}_{2}$ sinks. To the best of my knowledge, however, long-term studies observing the effect of biochar amendments on $\mathrm{SOM}$ in tropical Andosols do not exist. I am therefore unable to quantify the general potential for $\mathrm{C}$ sequestration with existing data, and any further discussion would enter into the realms of speculation. Nonetheless, I may at least compare my modelling results with the data available from short-term empirical studies in the region on biochar application and its effects. In the field trial, I observed that adding biochar to the local soil at a rate of around $2 \mathrm{~kg} / \mathrm{m}^{2}$ had no significant effect on soil total organic carbon (TOC) content (Krause et al. 2016). The theoretical potentials for biochar amendments in the msiri are estimated for annual or triennial biochar application rates of 0.3 or $0.8 \mathrm{~kg} / \mathrm{m}^{2}$, respectively, which correspond to $\mathrm{C}$ additions of approximately 0.2 or $0.6 \mathrm{~kg}$ $\mathrm{C} / \mathrm{m}^{2}$, respectively (Krause and Rotter 2018). These biochar amendments are, however, significantly lower than those recommended by Liu et al. (2012), or those in the practical experiences of Kimetu et al. (2008).

(E). Finally, all tested soil amendments can directly alter biomass production and crop yields (Krause et al. 2016). In the case of maize, CaSa-compost has the potential to quadruple grain yields in the short term (ibid.; Sect. 4.2). In the long term, and according to SWIM (Sect. 4.3), CaSa-compost and biogas slurry both have the potential to roughly double yields of maize grains. The empirical and analytical findings regarding the potential effects of CaSacompost and biogas slurry are, therefore, contradictory. I argue that, firstly, the stronger immediate effect displayed with CaSa-compost fertilisation is the possible result of a direct rise in soil $\mathrm{pH}$ through simultaneous liming. Soil $\mathrm{pH}$, however, is not a parameter in SWIM, even though it is highly relevant for predicting nutrient availability in the soil. Secondly, there is the possibility that SWIM overestimates $\mathrm{N}$ fertilisation and underestimates $\mathrm{P}$ fertilisation. With respect to beans, I found that a seasonal biomass growth of beans in fresh matter of at least $30 \mathrm{t} / \mathrm{ha}$ is needed to reach the break-even threshold where the balance of natural input and output flows of $\mathrm{N}$ turns from a net negative to a net positive result (Krause and Rotter 2018). This corresponds to a crop yield of about $3.8 \mathrm{t} / \mathrm{ha}$ of air-dried beans (ibid.). This yield has only been possible with the use of CaSa-compost as a fertiliser (Krause et al. 2016).

\section{Discussion of Opportunities and Challenges}

This section summarises important lessons learned with respect to real-world applications of the technologies analysed and the recycling fertilisation practices studied. Potential bottlenecks, and opportunities for how to overcome them, are identified regarding the use of biogas slurry, biochar and human excreta as, or in, recycling fertilisers. 


\subsection{Utilising Biogas Slurry as a Fertiliser}

I identified the following potential opportunities and challenges for the practical use of biogas slurry in smallholder farming.

\section{Biogas Slurry is an Adequate Fertiliser, but Not an 'Untapped Resource' in All Cases}

Locally available biogas slurry is characterised by nutrient contents (Table 5.1 in Krause et al. 2016) that are adequate for fertilisation, as compared to the literature (e.g. Finck 2007; Horn et al. 2010). Ample quantities of such biogas slurry are available for those smallholders operating a biogas digester (Krause and Rotter 2017). However, these material flows should not be considered as an 'untapped resource' for fertilising msiri fields, as both input materials for biogas fermentation have previously been used as fertiliser input in shambas, as shown by Baijukya and de Steenhuijsen Piters (1998). It is thus vital that biogas slurry is recycled into bananabased home gardens in order to replace prior inputs of banana stem and cow dung and to avoid an exacerbation of existing nutrient depletion in shamba systems (ibid.).

\section{Integrating Biogas Slurry in Soil Management May Create 'Islands of Soil Fertility'}

Farmers that already possess a BiogaST digester perform slurry management as follows. Some slurry is directly removed from the digester with buckets and used as a fertiliser. Further slurry leaves the digester through an outlet hole and flows via a small runlet into a pit filled with grasses and/or cow dung. After pre-composting in the pit, slurry is used to fertilise tomatoes in kitchen gardens, maize grown in msiri fields or banana plants in shambas. The latter practice is highly recommended, especially when banana stems are used as fermentation substrate (cf. prior paragraph). This practice potentially creates 'islands of soil fertility' in the vicinity of farm houses and, at the same time, accelerates existing 'discrete patterns of soil fertility', as described by Tittonell (2016). According to practical experience, a significant share of biogas slurry remains in the pit as the total amount available is too much for farmers to manage. This means, however, that the fertiliser effect of slurry is untapped, whilst greenhouse gas (GHG) emissions and nutrient leaching both increase.

\section{Fertilisation Benefits of Biogas Slurry Are Minor When Compared to the Effect of Compost}

When experimenting with biogas slurry as a soil amender, bean and maize plants did not respond as well to biogas slurry as to compost or to CaSa-compost (Krause et al. 2016). In addition, MAVUNO has observed that tomato plants developed bigger plants but rather small fruits when fertilised with biogas slurry in demonstration plots. Also, Komakech et al. (2015) did not find a specific advantage to using fermented matter compared to composted matter when studying biomass growth and crop yields of maize plants in Uganda. One possible explanation is that the comparatively high levels of $\mathrm{NH}+4$ and organic acids in biogas slurry are phytotoxic 
for plants (cf. Möller and Müller 2012; Salminen et al. 2001). Composting of biogas slurry with other organic matter could, therefore, reduce these phytotoxic substances, as demonstrated by Abdullahi et al. (2008). Farmers may directly exchange their practical experiences of using either liquid or composted biogas slurry for growing various local crops when meeting in 'biogas clubs'.

\section{Biogas Slurry Allows for a 'Target-Oriented' Fertiliser Application}

A specific opportunity and supposed advantage of biogas slurry, compared to compost, is the possibility to synchronise nutrient applications with crops' nutrient demands (Möller and Müller 2012). This 'target-oriented' fertiliser application is particularly relevant for crops with increased $\mathrm{N}$ demand (ibid.). Taking maize as an example, plant nutrient requirements are at their highest levels between 28 and 42 days after sowing (Kuratorium für Technik und Bauwesen in der Landwirtschaft (KTBL) 2009). Applying biogas slurry is, therefore, most highly recommended during this maturing stage.

\section{Net Effects on Gaseous Emissions After Slurry Application Are Not yet Quantifiable}

When using biogas slurry as a soil amender, $\mathrm{N}_{2} \mathrm{O}$ contributes significantly to GHG emissions from the agroecosystem, whilst $\mathrm{N}$ leaching and $\mathrm{NH}_{3}$ contribute marginally to eutrophication (Krause and Rotter 2018). Incorporating biogas slurry into the soil shortly (i.e. during the $12 \mathrm{~h}$ ) after application potentially avoids $\mathrm{N}_{2} \mathrm{O}$ and $\mathrm{NH}_{3}$ emissions, pursuant to Möller et al. (2008) and Möller and Stinner (2009). Farmers may use a hand-hoe to cover the slurry, or apply the slurry directly into a hole/furrow, which they then fill in immediately after. Furthermore, biogas slurry should preferably be applied to dry soil (ibid.). Amon et al. (2006) recommend a high water content of the slurry, or additional dilution of the slurry with water, to allow for rapid infiltration. The water content of local biogas slurry is approximately $95 \%$ of the fresh matter (Krause et al. 2015) and should thus be adequate for this purpose. When comparing the environmental impacts of using biogas slurry, compost or mulch, existing literature is ambiguous. In stockless organic cropping systems, for example, more than one-third of $\mathrm{N}_{2} \mathrm{O}$ emissions could be avoided by digesting crop residues before reallocation to fields, compared to using the same residues for mulching (Möller and Stinner 2009). In organic cropping systems with animal manuring, $\mathrm{NH}_{3}$ and $\mathrm{N}_{2} \mathrm{O}$ emissions and leaching of $\mathrm{NO}_{3}{ }^{-}$after application of biogas slurry are, meanwhile, comparable to those associated with applications of compost or mulching (Möller 2015). Overall, the major effect on environmental emissions after using biogas slurry, compost or mulch can be summarised as follows: on the one hand, high levels of $\mathrm{N}$ in biogas slurry from co-fermentation of cow dung increase $\mathrm{N}_{2} \mathrm{O}$ emissions as nitrification is promoted (Möller and Stinner 2009). On the other hand, comparatively low levels of organic $\mathrm{C}$ in biogas slurry potentially decrease $\mathrm{N}_{2} \mathrm{O}$ emissions as the activity of $\mathrm{C}$ decomposers (bacteria and fungi) is inhibited. This, in turn, reduces the availability of $\mathrm{NH}_{4}{ }^{+}$for nitrification and, thus, denitrification (Möller 2015). Overall, according to Möller (2015), field applications of biogas slurry primarily affect soil microbial activities, not GHG emissions. 


\subsection{Utilising Biochar for Composting}

I identified the following potential opportunities and challenges in regard to the practical use of biochar for composting.

\section{Total Recovery Potential of Biochar from Households Is Sufficient for CaSa-Composting}

Smallholder households cooking with microgasifiers potentially 'produce' biochar in fresh matter of 270-300 kg/year, respectively, depending on whether a sawdust gasifier or a TLUD is used (Krause and Rotter 2017). Finally, total potential to recover (maximum) biochar, on the one hand, and sanitised solids, on the other, results in comparable annual material flows in terms of volume (ibid.). This, in turn, fits very well into the practices required to produce CaSa-compost (Krause et al. 2015). After composting, about 2.6-2.8 $\mathrm{m}^{3}$ of CaSa-compost is available to smallholders each year (Krause and Rotter 2018). This amount is generally adequate and feasible for handling, carrying and amending compost in the soil (Sanchez et al. 1997). Furthermore, I add one personal experience from my scientific experiments described in Krause et al. (2016). During the field trials, I observed that CaSacompost aided workability of the soil, by making it more friable, presumably due to the biochar content. However, I did not make any scientific analysis to follow up on this anecdotal observation.

\section{Biochar Promotes Liming and, Thus, Improves the Efficiency of Nutrient Recycling}

Nutrient availability in the soil is, amongst other factors, an outcome of soil $\mathrm{pH}$ (Horn et al. 2010). The optimal topsoil pH range for cropping is 5.5-6.5 (ibid.). To buffer acids in soils, and thus to neutralise soil acidity, common measures include the use of lime ( $\mathrm{CaCO} 3$ ) (ibid.) and/or the addition of organic material (e.g. Wong et al. 1998). The addition of biochar is also associated with soil liming (cf. Biederman and Harpole 2013; Jeffery et al. 2011; Liu et al. 2013). In this respect, I found that biochar-containing CaSa-compost is characterised by a higher liming potential (per $\mathrm{kg}$ of $\mathrm{N}$ added to the soil) than biogas slurry, standard compost or other organic or synthetic fertilisers (Krause et al. 2015). This theoretically assessed liming potential is further practically effective in significantly increasing the soil $\mathrm{pH}$ to 6.1 within one season, compared with just 5.3 on unamended soil (Krause et al. 2016). In comparison, highly productive Terra Preta soils, which are particularly rich in biochar, are characterised by a $\mathrm{pH}$ of 5.2-6.4, comparatively higher than surrounding soils, as shown by Glaser and Birk (2012). The annual production of CaSa-compost is sufficient for application over a total area of $>1000 \mathrm{~m}^{2}$ per year and to maintain, or even improve, soil pH sustainably within this area (Krause and Rotter 2018). As a consequence, liming improves nutrient availability in the soil and renders nutrient cycling through organic residues more effective. 


\section{The Effects of Composting Biochar on Environmental Emissions Are Not yet Quantifiable}

Emissions from composting contribute significantly to overall environmental emissions from the agroecosystem (Krause and Rotter 2018). In particular, $\mathrm{CO}_{2}$ and $\mathrm{N}_{2} \mathrm{O}$ add to the global warming potential, whilst $\mathrm{NH}_{3}$ and $\mathrm{P}$ leaching contribute to eutrophication (ibid.). The fact that biochar captures $\mathrm{NO}_{3}{ }^{-}$and $\mathrm{PO}_{4}{ }^{3-}$, as shown, for example, by Agyarko-Mintah et al. (2016), Gronwald et al. (2015) and Kammann et al. (2015), is promising in regard to reducing GHG emissions and nutrient leaching during composting and also after compost is added to the soil. There is also empirical evidence that adding biochar to composting can decrease $\mathrm{N}_{2} \mathrm{O}$ and $\mathrm{CH}_{4}$ emissions (e.g. Agyarko-Mintah et al. 2016; Sonoki et al. 2013; Vandecasteele et al. 2013; Wang et al. 2014). When co-composting biochar with urine, as is practised in CaSa-composting, $\mathrm{NH}_{3}$ emissions still rise, but the increase observed is lower than after solely adding urine to compost (Larsen and Horneber 2015). Similarly, $\mathrm{N}_{2} \mathrm{O}$ and $\mathrm{CH}_{4}$ emissions also decrease, when adding urine and biochar to compost, whilst those emissions increase when only urine is added (ibid.). Results from observing changes in soil-borne emissions after using biochar are more ambiguous. According to Cayuela et al. (2014) and Zhang et al. (2012), N2O emissions from biochar amended soils are lower than those from unamended soils. Additionally, net fluxes of $\mathrm{CH}_{4}$ from managed soils decrease after biochar amendment (ibid.). This depends, however, on soil moisture levels and oxygenation (Van Zwieten et al. 2015). In contrast, other researches have found increased emissions of $\mathrm{N}_{2} \mathrm{O}$ (Singh et al. 2010), as well as of $\mathrm{CO}_{2}$ and $\mathrm{CH}_{4}$ (e.g. Spokas et al. 2009; Zhang et al. 2012), after amending biochar to soils. Overall, existing scientific data still exposes uncertainties in various areas and knowledge gaps in relation to the underlying principles and mechanisms at play (cf. Mukherjee and Lal 2014; Van Zwieten et al. 2015). It remains, therefore, a challenge to quantify changes in net emissions from an agroecosystem which utilises biochar for composting and soil fertility management.

\subsection{Utilising Faeces as a Compost Additive}

I identified the following potential opportunities and challenges for the practical use of faeces for composting.

\section{Human Faeces Contribute Significantly to the Nutrient Content of Compost, Especially $\mathbf{P}$}

An important aspect of CaSa-compost is its comparatively high nutrient content (Krause et al. 2015). Contents of $\mathrm{P}_{\text {tot }}$ and $\mathrm{N}_{\min }$, for example, are about three times higher in CaSa-compost than in Karagwe standard compost (ibid.). My findings are supported by considerable Ptot and Nmin concentrations in composts blended with faeces, as compared to compost without the addition of faeces, as per another experiment I took part in (Krause and Klomfaß 2015). Given that faeces are characterised by significantly higher $\mathrm{P}$ content than, for example, grass cuttings or kitchen waste 
(cf. Krause and Rotter 2018), the remarkably high P content in CaSa-compost can be attributed to co-composted human faeces. My model-based analysis shows that human faeces contribute about one-quarter of the P contained in CaSa-compost (ibid.). In view of the fact that P scarcity is a major soil constraint threatening farmers in Karagwe, this is a highly significant and beneficial aspect of utilising human faeces in agriculture.

\section{Faecal Compost Increases Crop Growth, but Its Use Is Not Recommended for All Crops}

In the field experiment, I tested the viability of CaSa-compost to effectively increase biomass growth and yields for maize, beans, cabbage, onion and carrots (Krause et al. 2016). The benefits observed for CaSa-compost, which uses locally available nutrients, match those of significantly higher inputs of synthetic $\mathrm{N}$ fertiliser. Likewise, Andreev et al. (2016) have observed a higher increase in maize grain yields when using faecal-biochar compost, in comparison to synthetic fertilisers or animal manure, in Moldova. Consequently, maize plants grown in soil amended with faecal matter-blended compost take up significantly larger amounts of $\mathrm{P}$ and $\mathrm{N}$ than plants grown using standard compost (Krause et al. 2016; Krause and Klomfaß 2015). Adequate concentrations of those macronutrients can, therefore, be found in plant tissue and seeds (ibid.). Meanwhile, composts which contain human faeces should, in general, not be used for crops which grow underground, such as for onion, carrots, beetroot, potatoes, etc. (e.g. Richert et al. 2010). Nonetheless, as shown in the field trial, CaSa-compost was especially beneficial for cultivating maize and beans (Krause et al. 2016). The demo plots of MAVUNO further indicate the appropriateness of CaSa-compost for growing tomatoes.

\section{Human Excreta Can Alternatively Be Used for Growing Perennial Crops or for Reforestation}

If the use of human excreta for the production of annual crops is undesirable for farmers, there are other options for its agricultural use. For example, faecal compost could be applied to fields used for growing bamboo, fodder grasses such as elephant grass (Pennisetum purpureum, Miscanthus fuscus or Miscanthus violaceus) or other grasses, which can be used as a fodder or energy crop. Another option for utilising human excreta is for growing bananas in shambas. This practice is called omushote in Swahili and was common in Karagwe until pit latrines were installed in the region through 'development cooperations' in the 1940s (Rugalema et al. 1994). It would be possible to adapt this method to modern practice in the following way. Faeces are first collected in a double-vault UDDT and then pre-composted inside the toilet for a period lasting from several weeks to months. Pre-composted solids are then applied, on rotational basis, to planting holes for banana plant cuttings. Similarly, faeces may be applied to the planting holes for trees, including fruit trees and trees for use as firewood or timber. To avoid transmission of diseases through direct contact or through flies, the hole needs to be covered ultimately with a layer of soil of about $30-50 \mathrm{~cm}$ in depth. Such reforestation could, for example, be realised on remote fields in the vicinity of settlements and thereby contribute to ameliorating degraded soils in these areas. 


\section{Mixing Human Faeces with Other Organic Matter Ensures Adequate Composting}

However, when faeces are employed for composting, they should always be mixed with other kinds of organic residues, such as kitchen waste, harvest residues and also biochar or ashes. The aim of this is to sustain a well-functioning composting process with a balanced mixture of (1) C-and nutrient-rich material, (2) fractions of easily degradable organics and of stable matter suitable for humification and (3) dry and wet matter (e.g. Amlinger et al. 2008; Heinonen-Tanski and van Wijk-Sijbesma 2005; Niwagaba et al. 2009).

\subsection{Utilising Urine as Fertiliser and Compost Additive}

I identified the following potential opportunities and challenges for the practical use of urine in agriculture.

\section{Different Means of Treating Urine Prior to Application to Reduce Odour}

It is likely that the most common method of using urine is as a liquid fertiliser diluted with water (Richert et al.2010). Urine is diluted mainly (1) to avoid excessive application of urine and (2) to reduce odour. If urine is used undiluted, Richert et al. recommend applying it to a furrow or hole and closing the furrow/hole with soil thereafter. This can reduce odour and $\mathrm{N}$ losses through sub-surface volatilisation. Lactic acid fermentation of urine is another option to reduce odour (e.g. Andreev et al. 2017). During the fermentation process, the lactic acid produced inhibits urease and, thus, also inhibits the formation of ammonia, whilst still conserving urea (ibid.). In practice, the lactic acid bacterial inoculum should be added to the empty urine storage tank of the UDDT before urine collection starts (ibid.). This increases the efficiency of lactic acid fermentation. Another approach to using urine as a fertiliser is the addition of magnesium oxide to stored urine, which results in a crystalline product called 'struvite', or magnesium ammonium phosphate (MAP) (Winker et al. 2011).

\section{Fertilising with Urine, in General, Promotes Plant Growth}

The beneficial effects of using urine as fertiliser have often been demonstrated (e.g. Andersson 2015; Esrey et al. 2001; Richert et al. 2010; Schönning and Stenström 2004). Arnold and Schmidt (2012) found that both treatments, stored urine and struvite, show equally good fertilising characteristics and are thus valid substitutes to synthetic fertiliser for cultivating maize, beans, summer wheat or Miscanthus. When testing the use of urine specifically for Karagwe (Krause et al. 2016), the urine's qualities as a fertiliser were altered inside the UDDT by passing it through a deodoriser block in the urinal. For this reason, the true benefit of urine fertilisation was not easy to gauge in our experiment. 


\section{Adding Urine Maintains a Well-Functioning Composting Process}

The benefits of adding urine to compost identified in this study are as follows: (1) urine contributes to moisture levels in the mixture; (2) urine enriches the compost product with $\mathrm{N}$ and $\mathrm{P}$; and (3) adding urine to compost can reduce workload for farmers. In regard to the first point, practical experience from the CaSa case study showed that adding urine to the compost pit was highly effective in order to avoid the matter drying out in local climate conditions in Karagwe. As water is scarce in the region, utilising urine solves this problem without the need for extra (fresh) water. To maintain a well-functioning composting process and to minimise $\mathrm{NH}_{3}$ and $\mathrm{N}_{2} \mathrm{O}$ emissions from the process, Amlinger et al. (2008) recommend a stable moisture content in the mixture of between $50 \%$ and $60 \%$ of the total fresh matter. In regard to the second point, to maintain a fast and odourless process and also to minimise GHG emissions, $\mathrm{C}$ and $\mathrm{N}$ in the compost mixture should be in the range of 25-35 (i.e. C/N ratio) (ibid.). The optimal $\mathrm{C} / \mathrm{N}$ range is determined by the needs of microorganisms, which require proportional content of $\mathrm{C}$ as an energy carrier and $\mathrm{N}$ for proteins (Finck 2007). Most materials added to compost tend to be rather rich in $\mathrm{C}$, and so the $\mathrm{C} / \mathrm{N}$ ratio of the resulting compost is often too high (ibid.), which slows down the process. According to my model, the $\mathrm{C} / \mathrm{N}$ ratio in Karagwe standard compost is about 43 and in CaSa-compost about 38 (Krause and Rotter 2018). Hence, the $\mathrm{C} / \mathrm{N}$ ratio in CaSa-compost is lower and therefore more proportional, presumably due to $\mathrm{N}$ input from urine. In regard to the third point, using urineblended compost can avoid an additional work step, when compared to applying compost prior to sowing or planting and then adding urine separately during plant growth.

\section{Enhancing Compost with Urine Potentially Decreases the Efficiency of $\mathbf{N}$ Recovery}

With regard to the overall efficiency of $\mathrm{N}$ recovery, I found that, theoretically, the $\mathrm{N}$-recovery potential is higher for the direct field application of urine than for its use as a compost additive, with approximately $70 \%$ and $55 \%$ of total $\mathrm{N}$ recovered, respectively (Krause and Rotter 2018). From a practitioner's perspective, there is, thus, a trade-off between optimising the efficiency of $\mathrm{N}$ recovery, improving the composting process and managing or reducing workload. Finally, since biochar can capture $\mathrm{NO}_{3}{ }^{-}$and $\mathrm{PO}_{4}{ }^{3-}$ (cf. Sect.4.2), the combined use of urine and biochar for composting also has the potential to reduce nutrient loss during, and after, composting and thus to positively affect the turnover of $\mathrm{N}$ and $\mathrm{P}$ and to make the practice of blending compost with urine more effective.

\section{Factors Surrounding Pharmaceuticals and Hormones in Urine Are, as yet, Largely Unstudied}

Finally, there are existing challenges in relation to 'health and hygiene' that relate to unknowns and uncertainties about 'organic micropollutants' (OMPs) contained in human excreta, such as pharmaceuticals, hormones, etc. Most OMPs are contained in urine, whilst faeces contain the larger part of pathogens (Richert et al. 2010). The eventual fate of these hazardous substances and the risk they pose to local populations is an important issue, which is, however, neither especially 
relevant to Karagwe nor specifically related to EcoSan. To the best of my knowledge, it is still unclear on a global scale how we will deal sustainably with different OMPs that we continuously and increasingly emit into the ecosystem. OMPs are also released into the environment through water toilets and pit latrines (e.g. Ngumba et al. 2016), most often in an uncontrolled manner and without any further treatment. Similarly, little is known about methods to eliminate OMPs in the environment, the prevalence of OMPs in the soil, their uptake by plants, further consequences for human health through consumption, the eco-toxicity of metabolisms, etc. It is certain, however, that simply storing urine is not sufficient to completely remove pharmaceuticals from urine. Struvite, meanwhile, is a product free of pharmaceuticals and pathogens (Schürmann et al. 2012). Furthermore, according to the WHO (2006), 'the soil system is generally better equipped than watercourses for the degradation of pharmaceutical residues'. Further to this point, Arnold (2012) observed the successful degradation of hormones in the soil. With respect to pharmaceuticals, Arnold and Schmidt (2012) demonstrated that diclofenac (painkiller), atenolol (beta blocker) and verapamil (high blood pressure treatment) are not transferred to crops when present in urine used as fertiliser. Carbamazepine (an epilepsy treatment), however, can be determined in maize grains and stalks, but in relatively low concentrations (ibid.). Furthermore, nitrification is a suitable process for removing certain pharmaceuticals, whilst filtration of urine with activated carbon is a viable way to remove all pharmaceuticals from urine (Bischel et al. 2015). However, secure disposal of used activated carbon needs to be solved.

\section{Conclusions}

In order to be considered 'sustainable', soil fertility management should, amongst other factors, mitigate existing soil constraints, such as nutrient depletion and soil acidity. In the contemporary context, it should also promote resilience for agriculture in the face of climate change as a local and global threat. SOM, and the restoration of SOM, is of equal importance to climate adaptation measures, as it contributes to the soil's water-holding capacity and erosion resistance. Ultimately, soil fertility management is applied in order to maintain or improve crop productivity. With respect to the potential identified for capturing residues from cooking and EcoSan for recycling-driven soil fertility management, I conclude that recovering and processing residues from smallholder households provides a significant opportunity to increase access to fertiliser and soil improvers through subsistence production. All treatments analysed are viable as substitutes for synthetic, commercial fertilisers, but $\mathrm{CaSa}$-compost displays benefits over and above the alternatives. The potential of CaSa-compost for 'sustainable' soil fertility management is superior to that of standard compost, especially with respect to liming and potential SOM restoration. Biogas slurry gives inferior results in all aspects when compared to compost amendments, but especially for liming, potential SOM restoration and GHG emissions. Moreover, even when the strong P-retention characteristics of the local Andosol are 
taken into consideration, further gradual increases in soil $\mathrm{P}$ are possible with regular applications of CaSa-compost. Both prevailing challenges for agricultural production in Karagwe - namely, P scarcity and soil acidification - can be mitigated through sufficient application rates of CaSa-compost, as the analysed case studies showed. Whether, and how, CaSa practice can also serve as a mitigation measure in relation to climate change could be the focus of future research. The demonstrated potential to increase yields is theoretically sufficient to enable food sovereignty for smallholder households, whilst the corresponding nutrient requirements are adequately compensated for by locally available residual matter. Therefore, this practical approach of recovering biochar and human excreta for soil fertility management represents an exit strategy from the vicious circle of poor soil quality and insufficient production of food crops and residual matter in the context of smallholdings in sub-Saharan Africa. Overall, my results endorse the establishment of a clear link between cooking, sanitation and agriculture and, therefore, an intersectional resource management' approach around the energy-sanitation-agriculture nexus. This is due to the fact that recyclable matter from energy and sanitation facilities has complementary benefits. For example, biochar from microgasifiers promotes the recycling of $\mathrm{C}$ for restoring SOM, whilst those residues collected from EcoSan facilities contribute to capturing nutrients for fertilisation.

\section{References}

Abdullahi, Y. A., Akunna, J. C., White, N. A., Hallett, P. D., \& Wheatley, R. (2008). Investigating the effects of anaerobic and aerobic post-treatment on quality and stability of organic fraction of municipal solid waste as soil amendment. Bioresource Technology, 99(18), 8631-8636.

Agyarko-Mintah, E., Cowie, A., Singh, B. P., Joseph, S., Van Zwieten, L., Cowie, A., Harden, S., \& Smillie, R. (2016). Biochar increases nitrogen retention and lowers greenhouse gas emissions when added to composting poultry litter. Waste Management, 61, 138-143.

Amlinger, F., Peyr, S., \& Cuhls, C. (2008). Green house gas emissions from composting and mechanical biological treatment. Waste Manage Resources, 26(1), 47-60.

Amon, B., Kryvoruchko, V., Amon, T., \& Zechmeister-Boltenstern, S. (2006). Methane, nitrous oxide and ammonia emissions during storage and after application of dairy cattle slurry and influence of slurry treatment. Agriculture, Ecosystems and Environment, 112(2), 153-162.

Andersson, E. (2015). Turning waste into value: Using human urine to enrich soils for sustainable food production in Uganda. Journal of Clean Production, 96, 290-298.

Andreev, N., Ronteltap, M., Lens, P. N., Boincean, B., Bulat, L., \& Zubcov, E. (2016). Lactofermented mix of faeces and bio-waste supplemented by biochar improves the growth and yield of corn (Zea mays L.). Agriculture, Ecosystems \& Environment, 232, 263-272.

Andreev, N., Ronteltap, M., Boincean, B., Wernli, M., Zubcov, E., Bagrin, N., Borodin, N., \& Lens, P. N. (2017). Lactic acid fermentation of human urine to improve its fertilizing value and reduce odour emissions. Journal of Environmental Management, 198, 63-69.

Arnold, U. (2012). Landwirtschaftliche Nutzung von Gelbwasser und MAP -praktischer Einsatz und rechtliche Rahmenbedingungen. Presentation at the conference 'New water infrastructure concepts for urban planning'. Eschborn, Germany.

Arnold, U., \& Schmidt, J. (2012). Research Project Sanitary Recycling Eschborn (SANIRESCH), Project component: Agricultural Production/Legal Situation. Deutsche Gesellschaft für Internationale Zusammenarbeit (GIZ). Eschborn, Germany. 
Baijukya, F. P., \& de Steenhuijsen Piters, B. (1998). Nutrient balances and their consequences in the banana-based land use systems of Bukoba district, northwest Tanzania. Agriculture, Ecosystems \& Environment, 71, 147-158.

Baijukya, F. P., De Ridder, N., \& Giller, K. E. (2006). Nitrogen release from decomposing residues of leguminous cover crops and their effect on maize yield on depleted soils of Bukoba District, Tanzania. Plant and Soil, 279(1-2), 77-93.

Batjes, N. H. (2011). Global distribution of soil phosphorus retention potential. ISRIC Report 2011/06, Wageningen University and Research Centre, Wageningen, Netherlands, 41.

Batjes, N. H., \& Sombroek, W. G. (1997). Possibilities for carbon sequestration in tropical and subtropical soils. Global Change Biology, 3(2), 161-173.

Biederman, L. A., \& Harpole, W. S. (2013). Biochar and its effects on plant productivity and nutrient cycling - A meta-analysis. GCB Bioenergy, 5(2), 202-214.

Bischel, H. N., Özel Duygan, B. D., Strande, L., McArdell, C. S., Udert, K. M., \& Kohn, T. (2015). Pathogens and pharmaceuticals in source-separated urine in eThekwini, South Africa. Water Research, 85, 57-65.

Buresh, R. J., Smithson, P. C., \& Hellums, D. T. (1997). Building soil phosphorus capital in Africa. In Replenishing soil fertility in Africa (Special Publication 51) (pp. 111-149). Chicago: Soil Science Society of America and American Society of Agronomy (SSSA).

CaSa. (2012). Project report from Engineers Without Borders for the pilot phase of the project "Carbonization and sanitation" in Karagwe, Tanzania.

Cayuela, M. L., Van Zwieten, L., Singh, B. P., Jeffery, S., Roig, A., \& Sánchez-Monedero, M. A. (2014). Biochar's role in mitigating soil nitrous oxide emissions: A review and metaanalysis. Agriculture, Ecosystems and Environment, 191, 5-16.

Chesworth, W. (Ed.). (2008). Encyclopedia of soil science (p. 902). Dordrecht: Springer.

Christensen, T. H., Gentil, E., Boldrin, A., Larsen, A., Weidema, B., \& Hauschild, M. (2009). C balance, carbon dioxide emissions and global warming potentials. Waste Manage Resources, 27(8), 707-715.

DeSchutter, O. (2011). Agroecology and the right to food. Report by the special rapporteur on the right to food of the United Nations (UN), presented at the 16th session of the UN Human Rights Council [A/HRC/16/49], Geneva, Switzerland.

dePauw, E. D. (1984). Soils, physiography and agro-ecological zones of Tanzania. Crop. Monitoring and Early Warning Systems Project. GCPS/URT/047/NET, Kilimo/FAO, Dar es Salaam.

Esrey, S. A., Andersson, I., Hillers, A., \& Sawyer, R. (2001). Closing the Loop - Ecological sanitation for food security. Publications on Water Resources No. 18. Swedish International Development Cooperation Agency (SIDA) Sweden/Mexico.

Falcão, N. P. S., Clement, C. R., Tsai, S. M., \& Comerford, N. B. (2009). Pedology, fertility, and biology of central Amazonian Dark Earths. In Amazonian dark earths: Wim Sombroek's vision (pp. 213-228). Dordrecht: Springer, Netherlands.

FAO. (2014). A statement by FAO director-general José Graziano da Silva. In 24th session of the Committee on Agriculture (COAG) opening statement. Rome: Food and agriculture Organization of the United Nations (FAO).

FAOSTAT. (2012). Statistics of the FAO, annual, data for: Maize; yield; all countries. Statistical Databases of the FAO.

Finck, A. (2007). Pflanzenernährung und Düngung in Stichworten (Plant nutrition and fertilization in keywords) (6th ed.). Stuttgart: Borntraeger.

Glaser, B., \& Birk, J. J. (2012). State of the scientific knowledge on properties and genesis of anthropogenic dark earths in Central Amazonia (terra preta de Índio). Geochima est Cosmochima Acta, 82, 39-51.

Gornott, C., Hattermann, F., \& Wechsung, F. (2015). Yield gap analysis for Tanzania - The impact of climate and management on Maize yields. In Poster presentation at 'Management of land use systems for enhanced food security - Conflicts, controversies and resolutions'. Berlin: Tropentag. 
Gornott, C., Hattermann, F., \& Wechsung, F. (2016). Liebig's law - Increase and stabilise Tanzanian Maize yields by combining different crop modelling approaches. In Oral presentation at 'Solidarity in a competing world - Fair use of resources. Vienna: Tropentag.

Graeub, B. E., Chappell, M. J., Wittman, H., Ledermann, S., Kerr, R. B., \& Gemmill-Herren, B. (2016). The state of family farms in the world. World Development, 85, 1-15.

Gronwald, M., Don, A., Tiemeyer, B., \& Helfrich, M. (2015). Effects of fresh and aged biochars from pyrolysis and hydrothermal carbonization on nutrient sorption in agricultural soils. Soil Discussions, 2, 29-65.

Heinonen-Tanski, H., \& van Wijk-Sijbesma, C. (2005). Human excreta for plant production. Bioresource Technology, 96(4), 403-411.

Horn, R., Brümmer, G. W., Kandeler, E., Kögel-Knabner, I., Kretzschmar, R., Stahr, K., \& Wilke, B. M. (2010). Scheffer/Schachtschabel - Lehrbuch der Bodenkunde (Textbook of soil science) (16th ed., p. 570). Heidelberg: Springer Spektrum.

Jeffery, S., Verheijen, F. G. A., van der Velde, M., \& Bastos, A. C. (2011). A quantitative review of the effects of biochar application to soils on crop productivity using meta-analysis. Agriculture, Ecosystems and Environment, 144(1), 175-187.

Kammann, C., Schmidt, H. P., Messerschmidt, N., Linsel, S., Steffens, D., Müller, C., Koyro, H. W., Conte, P., \& Stephen, J. (2015). Plant growth improvement mediated by nitrate capture in co-composted biochar. Nature Scientific Reports, 5(11080), 12.

Kenneth, F. G. Masuki, J., Mbogoni, G., \& Ley, J. (2003). Agro-ecological zones of the lake zone, Tanzania. In Lake Zone Agricultural Research and Development Institute (LZARDI) and National Soil Service, Agricultural Research Institute (ARI) Mlingano (p. 26). Tanzania.

Kimaro, A. A., Timmer, V. R., Chamshama, S. A. O., Ngaga, Y. N., \& Kimaro, D. A. (2009). Competition between maize and pigeonpea in semi-arid Tanzania: Effect on yields and nutrition of crops. Agriculture, Ecosystems and Environment, 134, 115-125.

Kimetu, J. M., Lehmann, J., Ngoze, S. O., Mugendi, D. N., Kinyangi, J. M., Riha, S., \& Pell, A. N. (2008). Reversibility of soil productivity decline with organic matter of differing quality along a degradation gradient. Ecosystems, 11(5), 726-739.

Komakech, A. J., Zurbrügg, C., Semakula, D., Kiggundu, N., \& Vinnerås, B. (2015). Evaluation of the performance of different organic fertilisers on maize yield: A case study of Kampala, Uganda. Journal of Agricultural Science, 7(11).

Krause, A. (2018). Valuing wastes - An integrated system analysis of bioenergy, ecological sanitation, and soil fertility management in smallholder farming in Karagwe, Tanzania. Dissertation at TU Berlin, Germany.

Krause, A., \& Klomfaß, J. (2015). Kohlenstoff- und Nährstoffrecycling mit Bioenergie- und ökologischen Sanitärsystemen. In Presentation at the workshop 'Biokohle im Gartenbau Verwertung von organischen Reststoffen zur Schließung von Energie- und Stoffkreisläufe'. Berlin: Botanical Garden.

Krause, A., \& Rotter, V. S. (2017). Linking energy-sanitation-agriculture: Intersectional resource management in smallholder households in Tanzania. Science of the Total Environment, 59, $514-530$.

Krause, A., \& Rotter, V. S. (2018). Recycling improves soil fertility management in smallholdings in Tanzania. Agriculture, 8(3), 31.

Krause, A., Kaupenjohann, M., George, E., \& Koeppel, J. (2015). Nutrient recycling from sanitation and energy systems to the agroecosystem - Ecological research on case studies in Karagwe, Tanzania. African Journal of Agricultural Research, 10(43), 4039-4052.

Krause, A., Nehls, T., George, E., \& Kaupenjohann, M. (2016). Organic wastes from bioenergy and ecological sanitation as a soil fertility improver: A field experiment on a tropical Andosol. The Soil, 2, 147-162.

Krysanova, V., Wechsung, F., Arnold, J., Srinivasan, R., \& Williams, J. (2000). SWIM (Soil and Water Integrated Model) user manual. PIK Report Nr. 69, p. 239. 
KTBL. (2009). Faustzahlen für die Landwirtschaft (Rule-of-thumb figures for agriculture). Kuratorium für Technik und Bauwesen in der Landwirtschaft (KTBL) (14th edn.). Darmstadt, Germany.

La Via Campesina. (2015). Declaration of the International Forum for Agroecology.

Lal, R. (2006). Managing soils for feeding a global population of 10 billion. Journal of the Science of Food and Agriculture, 86(14), 2273-2284.

Lal, R. (2009). Soils and world food security. Soil \& Tillage Research, 102(1), 1-4.

Landon, J. R. (1991). Booker tropical soil manual: a handbook for soil survey and agricultural land evaluation in the tropics and subtropics. 1st paperback edition (p. 474). Essex: Longman Scientific \& Technical Ltd.

Larsen, O., \& Horneber, D. (2015). Einfluss von Biokohle auf Treibhausgasemissionen während der Kompostierung.In K. Terytze (Ed.), Book of abstracts of the scientific workshop "Biokohle im Gartenbau - Verwertung von organischen Reststoffen zur Schließung von Energie- und Stoffkreisläufen" (pp. 33-34). Berlin, Germany.

Lehmann, J., \& Joseph, S. (2009). Biochar for environmental management - Science and technology. Sterling: Earthscan.

Liu, J., Schulz, H., Brandl, S., Miehtke, H., Huwe, B., \& Glaser, B. (2012). Short-term effect of biochar and compost on soil fertility and water status of a dystric Cambisol in NE Germany under field conditions. Journal of Plant Nutrition and Soil Science, 175, 698-707.

Liu, X., Zhang, A., Ji, C., Joseph, S., Bian, R., Li, L., \& Paz-Ferreiro, J. (2013). Biochar's effect on crop productivity and the dependence on experimental conditions-A meta-analysis of literature data. Plant and Soil, 373(1-2), 583-594.

Markwei, C., Ndlovu, L., Robinson, E., \& Shah, W. P. (2008). International Assessment of Agricultural Knowledge, Science and Technology for Development (IAASTD): Sub-Saharan Africa summary for decision makers. Washington, DC: Island Press.

McIntyre, B. D., Herren, H. R., Wakhungu, J., \& Watson, R. T. (2009). Agriculture at a crossroads. In IAASTD: Global report. Washington, DC: Island Press.

Möller, K. (2015). Effects of anaerobic digestion on soil carbon and nitrogen turnover, N emissions, and soil biological activity. A review. Agronomy for Sustainable Development, 35(3), $1021-1041$.

Möller, K., \& Müller, T. (2012). Effects of anaerobic digestion on digestate nutrient availability and crop growth: A review. Engineering in Life Sciences, 12(3), 242-257.

Möller, K., \& Stinner, W. (2009). Effects of different manuring systems with and without biogas digestion on soil mineral nitrogen content and on gaseous nitrogen losses (ammonia, nitrous oxides). European Journal of Agronomy, 30(1), 1-16.

Möller, K., Stinner, W., Deuker, A., \& Leithold, G. (2008). Effects of different manuring systems with and without biogas digestion on nitrogen cycle and crop yield in mixed organic dairy farming systems. Nutrient Cycling in Agroecosystems, 82(3), 209-232.

Mourice, S. K., Rweyemamu, C. L., Tumbo, S. D., \& Amuri, N. (2014). Maize cultivar specific parameters for decision support system for agrotechnology transfer (DSSAT) application in Tanzania. American Journal of Plant Sciences, 5, 821-833.

Mukherjee, A., \& Lal, R. (2014). The biochar dilemma. Soil Resources, 52, 217-230.

Ngumba, E., Gachanja, A., \& Tuhkanen, T. (2016). Occurrence of selected antibiotics and antiretroviral drugs in Nairobi River Basin, Kenya. Science of the Total Environment, 539, 206-213.

Niwagaba, C., Nalubega, M., Vinnerås, B., Sundberg, C., \& Jönsson, H. (2009). Bench-scale composting of source-separated human faeces for sanitation. Waste Management, 29(2), 585-589.

Nziguheba, G. (2001). Improving phosphorus availability and maize production through organic and inorganic amendments in phosphorus deficient soils in western Kenya. Doctoral thesis, dissertationes de agricultura no. 462, Katholieke Universiteit Leuven, Belgium.

Ogola, S. A. (2013). Land and natural resources conflict in transboundary agroecosystem management project Kagera basin. Assessment report to project 'Kagera Agro-Ecosystems'. FAO, Rome, Italy. 
Peel, M. C., Finlayson, B. L., \& McMahon, T. A. (2007). Updated world map of the Köppen-Geiger climate classification. Hydrology and Earth System Sciences Discussions, 4(2), 439-473.

Richert, A., Gensch, R., Jönsson, H., Stenström, T-A., \& Dagerskog, L. (2010). Practical guidance on the use of urine in crop production. Stockholm Environment Institute (SEI), EcoSanRes Programme, Stockholm.

Rugalema, G. H., Okting'Ati, A., \& Johnsen, F. H. (1994). The homegarden agroforestry system of Bukoba district, North-Western Tanzania. 1. Farming system analysis. Agroforestry Systems, 26(1), 53-64.

Salminen, E., Rintala, J., Härkönen, J., Kuitunen, M., Högmander, H., \& Oikari, A. (2001). Anaerobically digested poultry slaughterhouse wastes as fertiliser in agriculture. Bioresource Technology, 78(1), 81-88.

Sanchez, P. A., Shepherd, K. D., Soule, M. J., Place, F. M., Buresh, R. J., Izac, A. M. N., Mokwunye, U., Kwesiga, F. R., Ndiritu, C. G., \& Woomer, P. L. (1997). Soil fertility replenishment in Africa: An investment in natural resource capital. Replenishing soil fertility in Africa. Soil Science Society of America, 51, 1-46.

Schönning, C., \& Stenström, A. T. (2004). Guidelines for the safe use urine and faeces in ecological sanitation systems. In Swedish Institute for infectious disease control, EcoSanRes Programme. Stockhoml: SEI.

Schrecker, S. (2014). Konstruktionsplanung eines Brenners zur Nutzung von Biogas als Kochwärme und experimentelle Effizienzbestimmung für die lokale Implementierung in Tansania. Diploma/ Master thesis, TU Berlin, Germany.

Schürmann, B., Everding, W., Montag, D., \& Pinnekamp, J. (2012). Fate of pharmaceuticals and bacteria in stored urine during precipitation and drying of struvite. Water Science and Technology, 65(10), 1774-1780.

Singh, B. P., Hatton, B. J., Singh, B., Cowie, A. L., \& Kathuria, A. (2010). Influence of biochars on nitrous oxide emission and nitrogen leaching from two contrasting soils. Journal of Environmental Quality, 39, 1224-1235.

Sonoki, T., Furukawa, T., Jindo, K., Suto, K., Aoyama, M., \& Sánchez-Monedero, M. Á. (2013). Influence of biochar addition on methane metabolism during thermophilic phase of composting. Journal of Basic Microbiology, 53(7), 617-621.

Spokas, K. A., Koskinen, W. C., Baker, J. M., \& Reicosky, D. C. (2009). Impacts of woodchip biochar additions on greenhouse gas production and sorption/degradation of two herbicides in a Minnesota soil. Chemosphere, 7, 574-581.

Springmann, M., Clark, M., Mason-D’Croz, D., Wiebe, K., Bodirsky, B. L., Lassaletta, L., De Vries, W., Vermeulen, S. J., Herrero, M., Carlson, K. M., et al. (2018). Options for keeping the food system within environmental limits. Nature, 562(7728), 519.

Tittonell, P. (2016). Feeding the world with soil science: Embracing sustainability, complexity and uncertainty. Soil Discussions, in review.

UNEP. (2007). Reactive nitrogen in the environment: Too much or too little of a good thing. Paris: United Nations Environment Programme (UNEP).

URoT. (2012). National sample census of agriculture 2007/2008.Regional report - Kagera region, volume Vh. United Republic of Tanzania, Ministry of Agriculture, Food Security and Cooperatives, The National Bureau of Statistics and the Office of the Chief Government Statistician, Zanzibar, Tanzania.

Van Zwieten, L., Kammann, C., Cayuela, M., Singh, B. P., Joseph, S., Kimber, S., Donne, S., Clough, T., \& Spokas, K. A. (2015). Biochar effects on nitrous oxide and methane emissions from soil. In Biochar for environmental management (pp. 489-520). London: Routledge.

Vandecasteele, B., Mondini, C., D’Hose, T., Russo, S., Sinicco, T., \& Quero Alba, A. (2013). Effect of biochar amendment during composting and compost storage on greenhouse gas emissions, $\mathrm{N}$ losses and $\mathrm{P}$ availability. In Proceedings of 15th RAMIRAN international conference, recycling of organic residues in agriculture. Versailles, France. 
Wang, Y., Dong, H., Zhu, Z., Li, T., Mei, K., \& Xin, H. (2014). Ammonia and greenhouse gas emissions from biogas digester effluent stored at different depths. Transactions of the ASABE, 57(5), 1483-1491.

WHO. (2006). WHO guidelines for the safe use of wastewater, excreta and greywater - Volume 4. Excreta and greywater use in agriculture. Geneva: World Health Organization (WHO), WHO Press.

Willett, W., Rockström, J., Loken, B., Springmann, M., Lang, T., Vermeulen, S., et al. (2019). Food in the Anthropocene: The EAT-lancet commission on healthy diets from sustainable food systems. The Lancet, 393(10170), 447-492.

Winker, M., Paris, S., Heynemann, J., \& Montag, D. (2011). Phosphorrückgewinnung aus Urin mittels Struvitfällung in einem Frankfurter Bürogebäude. fbr-wasserspiegel, 1(11), 3-4.

Wong, M. T. F., Nortcliff, S., \& Swift, R. S. (1998). Method for determining the acid ameliorating capacity of plant residue compost, urban waste compost, farmyard manure, and peat applied to tropical soils. Communications in Soil Science \& Plant Analysis, 29(19-20), 2927-2937.

Zakharova, A., Beare, M. H., Cieraad, E., Curtin, D., Turnbull, M. H., \& Millard, P. (2015). Factors controlling labile soil organic matter vulnerability to loss following disturbance as assessed by measurement of soil-respired $\delta^{13} \mathrm{CO}_{2}$. European Journal of Soil Science, 66(1), 135-144.

Zhang, A., Liu, Y., Pan, G., Hussain, Q., Li, L., Zheng, J., \& Zhang, X. (2012). Effect of biochar amendment on maize yield and greenhouse gas emissions from a soil organic carbon poor calcareous loamy soil from Central China Plain. Plant and Soil, 351, 263-275.

The opinions expressed in this chapter are those of the author(s) and do not necessarily reflect the views of the United Nations University Institute for Integrated Management of Material Fluxes and of Resources (UNU-FLORES), its Board of Directors, or the countries they represent.

Open Access This chapter is licensed under the terms of the Creative Commons Attribution 3.0 IGO license (https://creativecommons.org/licenses/by/3.0/igo/), which permits use, sharing, adaptation, distribution and reproduction in any medium or format, as long as you give appropriate credit to the United Nations University Institute for Integrated Management of Material Fluxes and of Resources (UNU-FLORES), provide a link to the Creative Commons license and indicate if changes were made.

Any dispute related to the use of the works of the United Nations University Institute for Integrated Management of Material Fluxes and of Resources (UNU-FLORES) that cannot be settled amicably shall be submitted to arbitration pursuant to the UNCITRAL rules. The use of the United Nations University Institute for Integrated Management of Material Fluxes and of Resources (UNU-FLORES)'s name for any purpose other than for attribution, and the use of the United Nations University Institute for Integrated Management of Material Fluxes and of Resources (UNU-FLORES)'s logo, shall be subject to a separate written license agreement between the United Nations University Institute for Integrated Management of Material Fluxes and of Resources (UNU-FLORES) and the user and is not authorized as part of this CC-IGO license. Note that the link provided above includes additional terms and conditions of the license.

The images or other third party material in this chapter are included in the chapter's Creative Commons license, unless indicated otherwise in a credit line to the material. If material is not included in the chapter's Creative Commons license and your intended use is not permitted by statutory regulation or exceeds the permitted use, you will need to obtain permission directly from the copyright holder.

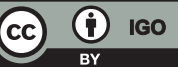

